Historic, Archive Document

Do not assume content reflects current scientific knowledge, policies, or practices. 




\section{Preliminary Notes.}

FERNS have been a prominent feature in our Catalogue for many years. There are no plants that give better satisfaction and require so little care as these.

POSTPAID. We will deliver at your post office the Ferns, Hardy Perennials, Bog and Aquatic Plants and Orchids given in this Catalogue at prices named.

TREES, SHRUBS and ROSES. These are too heavy for the mail, but they will be delivered at the express or freight office here, the purchaser paying transportation charges when goods are received. When stock can be packed in small boxes no charge is made, but when larger boxes or bales are used a charge will be made to cover actual cost.

IN MANY CASES, where the distance is not too great, parties would find it to their advantage to have their stock of Ferns and Hardy Perennials sent by express, as heavier or more bulky plants could be sent in this way that could not go by mail.

EXPRESS RATES. The express company here (Adams) offers to carry nursery stock at a reduction of 20 per cent discount from the regular rate. Thirty-five pounds can be sent to Boston or New York for 35 cents; and I cent for each additional pound: roo pounds go for 80 cents. Eleven pounds can be sent to Chicago for 35 cents and 3 cents for each additional pound.

REMITTANCES may be made by Registered Letter, by Post Office Money Order on Southwick, Mass., or by draft.

CERTIFICATE OF INSPECTICN. A copy will be sent to purchasers when desired. Address all communications to

EDWARD GILLETT, SOUTHWICK, MASS.

\section{CONTENTS.}

Hardy Ferns ........................ . . . . . . . . . . . . . .

Collection of Ferns . . . . . . . . . . . . . . . . . . . . . . . . .

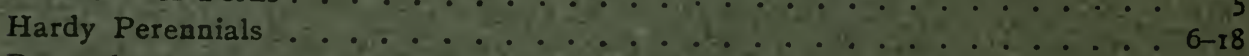

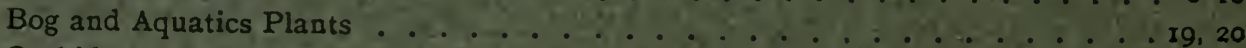

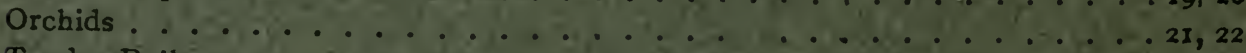

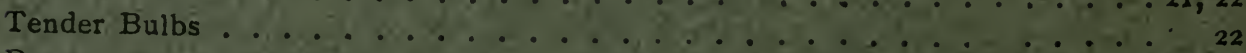

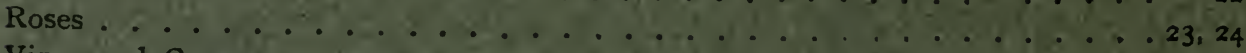

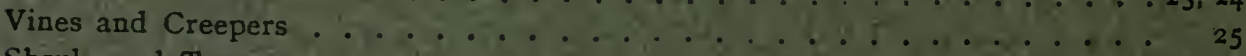

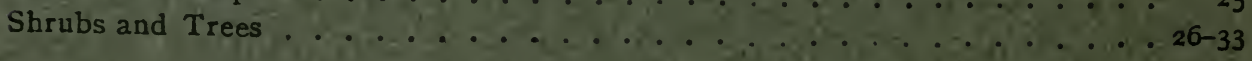

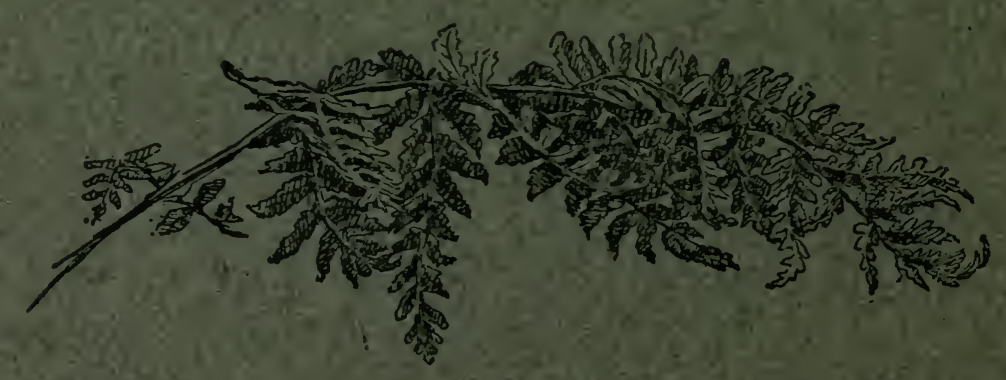




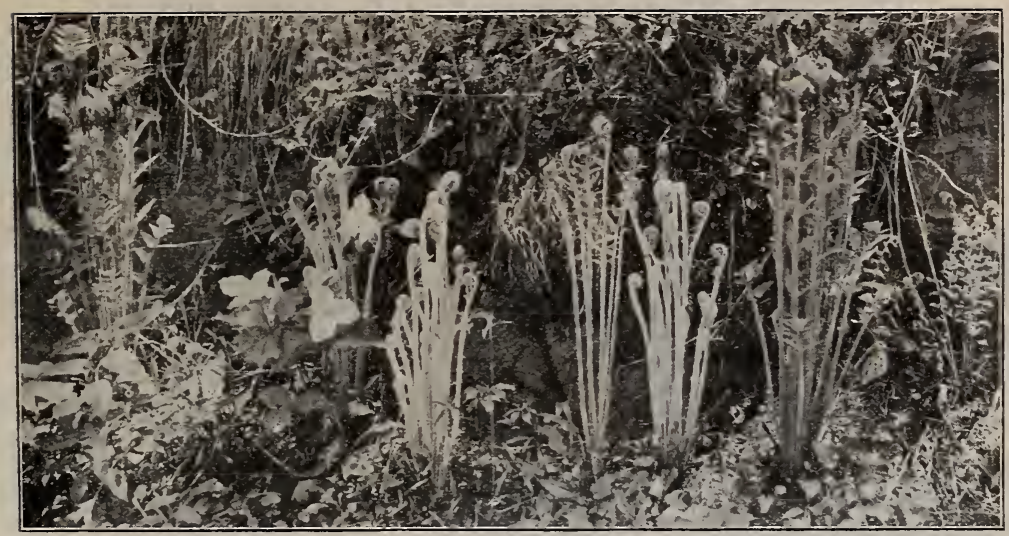

Unfolding fronds of the Osmundas. (See page 4.)

\section{Hardy Ferns.}

The Ferns take as readily to cultivation as the common garden flowers, and when once planted, will grow on year after year. While flowers require a sunny place, Ferns delight in some shaded nook, shut out from the bright sunlight by trees or other shade. Use some leaf-mold mixed with light garden soil in planting, yet many of the common and larger Ferns will thrive in almost any soil where columbines will grow.

ADIANTUM pedatum (Maidenhair Fern). One of the prettiest. Grows about a foot high, in rich shades, and responds readily to cultivation. This, like nearly all the Ferns, needs good drainage. It will establish itself in one season, and increase in strength year after year. Clumps, $20 \mathrm{cts}$. each, $\$$ I. 25 per doz. clumps.

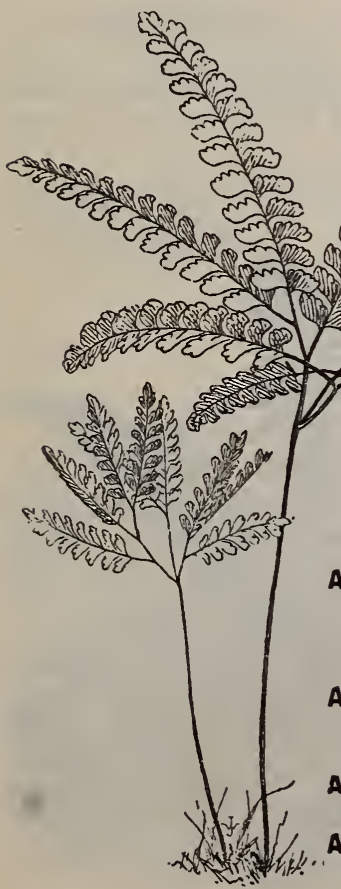

ASPIDIUM acrostichoides (Christmas Fern). An evergreen species, about a foot high, with deep green fronds, simply divided. Although it is one of our common species, it is a pretty one, and easily grown in good garden soil well drained. I5 cts. each, \$I per doz.

A. aculeatum, var. Braunii. A more local species, growing along the margins of mountain brooks. The fronds are often 2 feet in length by 6 inches in width. Shining fronds, which are evergreen. 20 cts. each, \$I.50 per doz.

A. cristatum. This species grows from I to 2 feet high, in wet, swampy places, with fronds about 3 inches wide. Io cts. each, \$I per doz.

A. cristatum, var. Clintonianum. In every way larger than the preceding, sometimes attaining a height of $4 \mathrm{feet}$, with fronds nearly a foot wide. This is a showy Fern, and not difficult to grow. I5 cts each, $\$ 1.25$ per doz.

A. Boottii. An intermediate form between A. cristatum and A. spinulosum found sparingly in swamps. Plant it in with A. cristatum. $20 \mathrm{cts}$ each, $\$ 2$ per doz.

A. Filix-mas (Male Fern). A very beautiful and hardy Fern, green all the year. Rare. $30 \mathrm{cts}$

A. Goldianum (Goldie's Wood Fern). This species often grows 4 feet high, with fronds a foot or more wide. Broadly ovate in outline, deep green in color. Takes kindly to cultivation in Adiantum pedatum. moist shades. Not evergreen. $20 \mathrm{cts}$ each, \$I.50 per doz. 
ASPIDIUM marginale. One of our prettiest evergreen species. Fronds I to 2 feet in length, 3 to 5 inches wide, thickish, and of a deep green color. It delights in rich shady hillsides, yet it thrives in my garden with Maidenhair and other kinds.

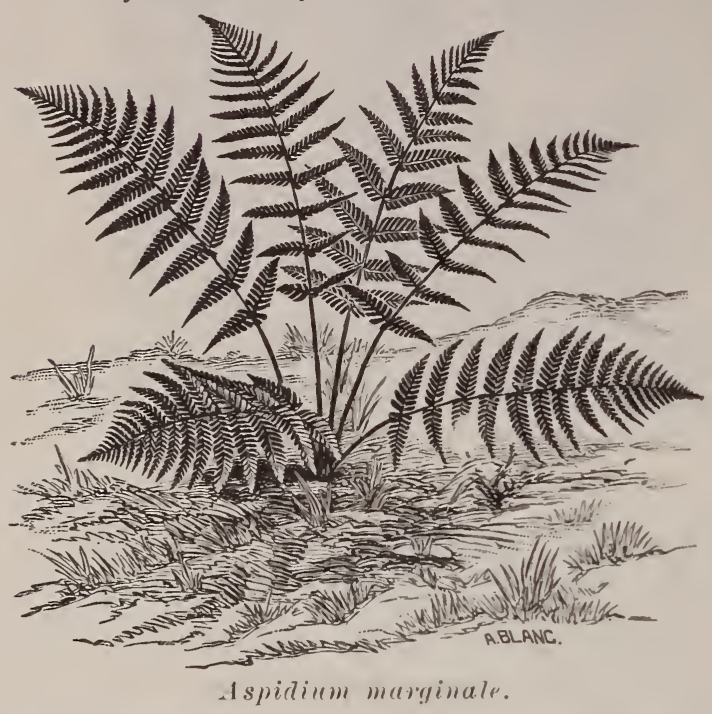

I 5 cts. each, \$I per doz.

A. Noveboracense. A slender species about a foot high, in moist, shady woods, with fronds 3 to 4 inches wide. Pale green, delicate and membranaceous. I $5 \mathrm{cts}$. each, $\$$ I per doz.

A. spinulosum. A very pretty evergreen species, about 15 inches high, with finely dissected fronds about 4 inches wide. It is easily grown in a moist, shady location. Io cts. each, $\$$ I per doz.

A. spinulosum, var. dilatatum. Similar to the above, but with broader fronds. $25 \mathrm{cts}$. each, $\$ 2$ per doz.

A. Thelypteris. A foot high, with fronds about $2 \frac{1}{2}$ inches wide. Well adapted for boggy places where it is quite wet. I5 cts. each, \$I per doz.

ASPLENIUM angustifolium. A charming Fern with light green and graceful fronds. Do not miss it in making up your list. Grows I to 3 feet high, with simply divided fronds; these divisions are 3 to 4 inches long. Rich, molst shades. 20 cts. each, $\$ 1.25$ per doz.

A. ebeneum. Usually 6 to $\mathrm{I}_{5}$ inches high. Found growing among the rocks and along cliffs, in dry, rather sunny places. Suited for rockwork. Ioc. ea., \$I per doz.

A. Felix-fœmina. A large handsome Fern with finely cut foliage. Plant in moist place in sun or shade. I5 cts. each, \$1.25 per doz.

A. thelypteroides. Fronds 2 to 3 feet high by 6 inches wide. In moist shades. I5 cts. each, \$I per doz.

A. Trichomanes. A delicate little Fern, with narrow fronds 3 to 6 inches long. This, although found up among the cliffs, adapts itself to the small rockery, where it does exceedingly well. Clumps. I 5 cts. each, \$I.20 per doz.

BOTRYCHIUM Virginicum (Moonwort). Tall and ample, divided into two segments above the middle, one of which is erect, bearing the fruit; the other spreading, triangular, membranaceous and much divided. Shades. I $5 \mathrm{cts}$. each, \$1.25 per doz.

B. ternatum. 6 to 12 inches high. Fronds evergreen, somewhat resembling the preceding, but smaller and less divided. Open sun. Io cts. each, \$I per doz.

CAMPTOSORUS $r$ hizophyllus (Walking Leaf). A little lowcreeping Fern with evergreen fronds, 4 to 9 inches long, growing in tufts. The ends of these fronds rest on the ground and take root, forming new plants at each "step" thus taken. This curious habit has given the Fern its popular name. Found growing naturally on shaded, calcareous rocks. Interesting and quite easy to grow in the rock garden. Ioc. each, \$I per doz.

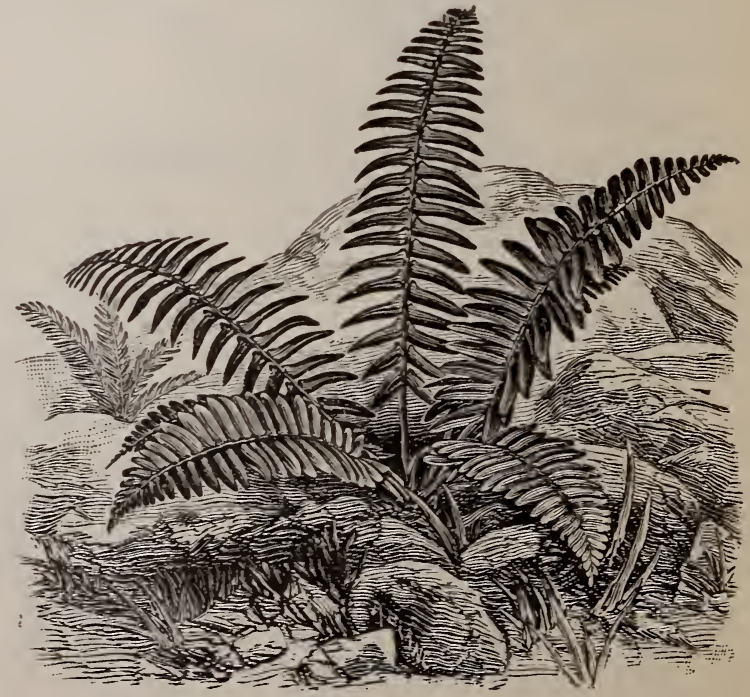

Aspidium acrostichoides. (See page I.) 
CHEILANTHES vestita. A beautiful little evergreen Fern, found in rccky places southward. I 5 cts. each, $\$$ I. 25 per doz.

CRYPTOGRAMME acrostichoides. A small Fern about 8 inches high. A native of the Pacific coast. Does quite well in the rock-garden. $20 \mathrm{cts}$.

CYSTOPTERIS bulbifera (Bladder Fern). Fronds I to 2 feet long, narrow and slender. Light green in color, and quite graceful. Grows best in shades. This makes a good plant for the fern basket. Io cts. each, \$I per doz.

C. fragilis. Smaller, 4 to 8 inches high; fronds 2 or 3 times divided. Io cts. each, \$I per doz.

DICKSONIA punctilobula. Grows 2 or 3 feet high. Fronds pale green, very thin, with strong stalks from a slender, creeping rootstock. A prominent feature in mountain scenery, often seen in great patches in open places. One of the very best for massing either in open sun or partial shade, and will thrive in quite dry or moist soil if the drainage is good. Easily grown. ro cts. each, \$r per doz.

LYCOPODIUM lucidulum (Shining Club Moss).

A pretty little evergreen, 3 to 8 inches high. Leaves $1 / 2$ inch long, growing thickly

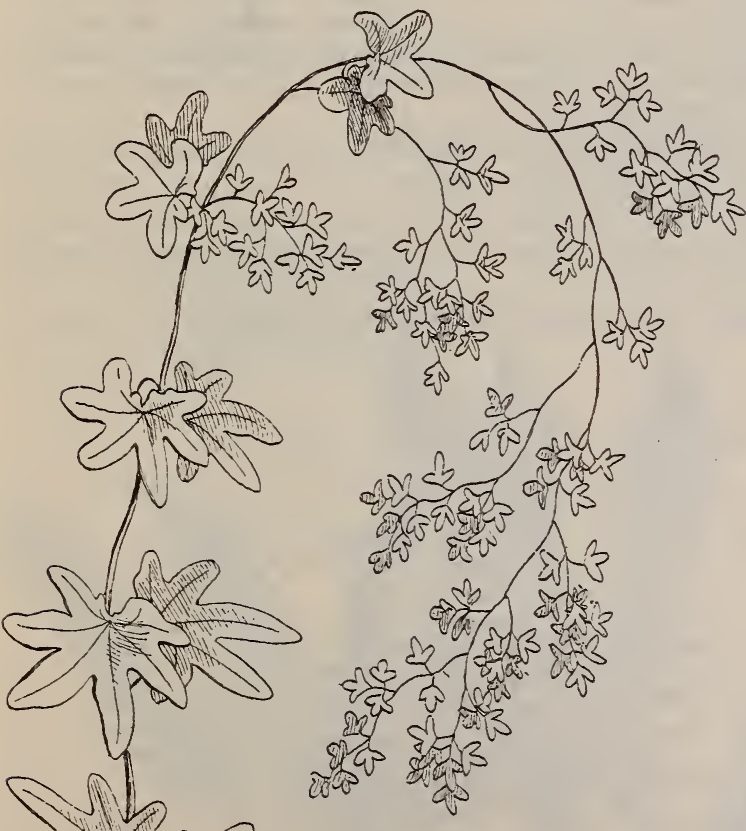
along the stalk. Moist soil. $20 \mathrm{cts}$. each, $\$ 1.25$ per doz,

LYGODIUM palmatum (Climbing Fern). Grows I to 3 feet high. Stalk slender and twining, from a slender running root-stock. 25 cts.

ONOCLEA sensibilis (Sensitive Fern). I to 2 feet high. Wet places, open sun or shade. In cts., each, \$I per doz.

o. Struthiopteris (Ostrich Fern). Fertile fronds about a foot high; sterile fronds much larger, I to 5 feet high, 6 to ro inches wide, erect. A very handsome species. Graceful as a palm on the lawn in open sun. $25 \mathrm{cts}$. each, \$1.50 per doz.

\section{OPHIOGLOSSUM vulgatum} (Adder's Tongue Fern). A single leaf from yellow fibrous roots, bearing at the top a singular spike of fruit or spores. Wet places. Ioc. each, \$I per doz.

OSMUNDA regalis (Flowering Fern). 2 to 3 feet high Pale green. One of the prettiest Ferns. Osmundas are adapted for open sun in moist places. Large roots. 30 cts. each, \$2 per doz.

0. Claytoniana. Is clothed with loose wool when unfolding its fronds in spring, soon becoming perfectly smooth. A group of these "white croziers" is shown on page 4. A hardy Fern, 2 to 3 feet in height,

Lygodium palmatum. fronds about 6 inches wide. $25 \mathrm{cts}$ each, $\$ 2$ per doz. 
OSMUNDA cinnamomea (Cinnamon Fern). Is usually larger than the preceding, often 5 feet high and 8 inches wide. Clothed with rusty wool when young, but

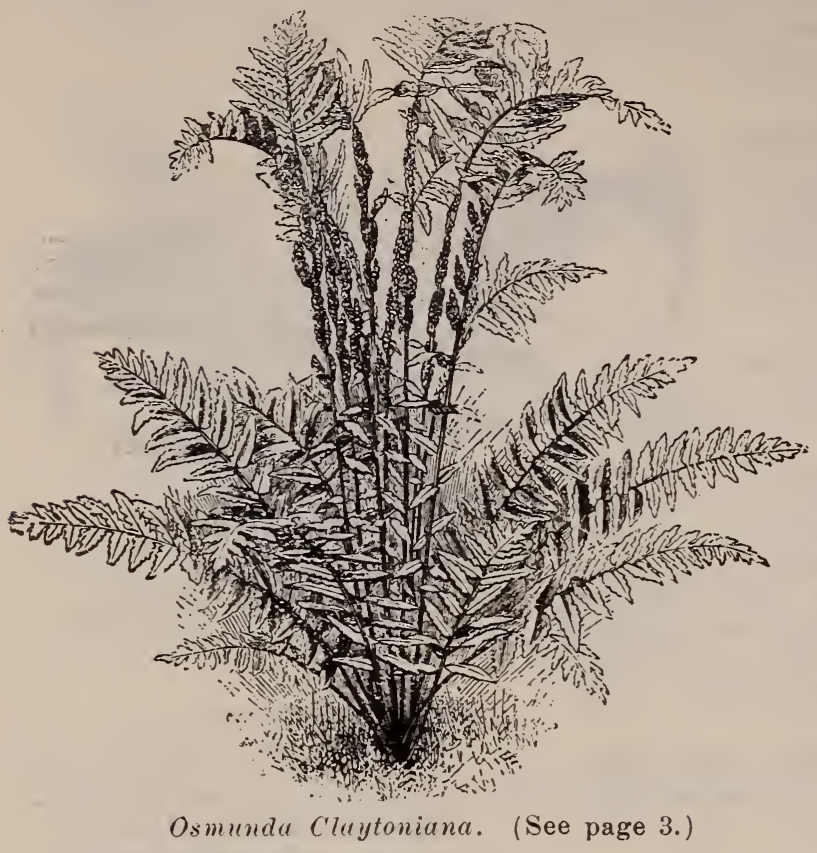
the sterile fronds are smooth when full grown. Very beautiful. 25c. each, $\$ 2$ per doz.

Pellza gracilis. A delicate little Fern, 3 to 6 inches high. Desirable for the rock garden. 25 cts. each, \$I.75 per doz.

PHEGOPTERIS (Beech Fern).-

P. Dryopteris. Has triangular fronds 3 to 5 inches wide, once or twice divided. A delicate and pretty Fern. In shades. I5 cts. each, $\$$ I per doz.

P. hexagonoptera. A good Fern for the shady corner, 7 to 12 inches wide, broader than long. Io cts. each, \$I per doz.

P. polypodoides. Fronds smaller and darker green than in the last. Rock garden or any garden soil in shade. Easily cultivated. Io cts. each, \$I per doz.

POLYPODIUM vulgare. One of the best evergreen species for rockwork. Grows 4 to ro inches high, forming dense mats. Generally found on half shaded rocks, often covering them. Io cts. each, \$I per doz.

P. falcatum. A species from Oregon, about the same size as the last, but more graceful. Same situation. I5 cts. each, \$I.25 per doz.

SELAGINELLA rupestris. A little, low, moss-like plant, I to 3 inches high, growing in little tufts, grayish green in color. Grows on exposed rocks. I5 cts. each, $\$ 1.20$ per doz.

S. apus. A pretty little creeper, with fine scale-like leaves. Desirable for a moist situ a tion, and makes a fine groundwork for s m a 11 flowering plants. IOc. each, \$ per doz.

W.OODSIA Ilvensis. This little Fern often chooses for its home the exposed rocks on tops of $\mathrm{mountains}$, forming little tufts and forcing its roots down in to the crevices. Twenty years ago I saw it in masses, in a beautiful garden, on $t$ he grounds where Mt. Tom House now stands in Holyoke, Mass., I,200 feet above the sea. 20 cts. ea, \$I 25 per doz.

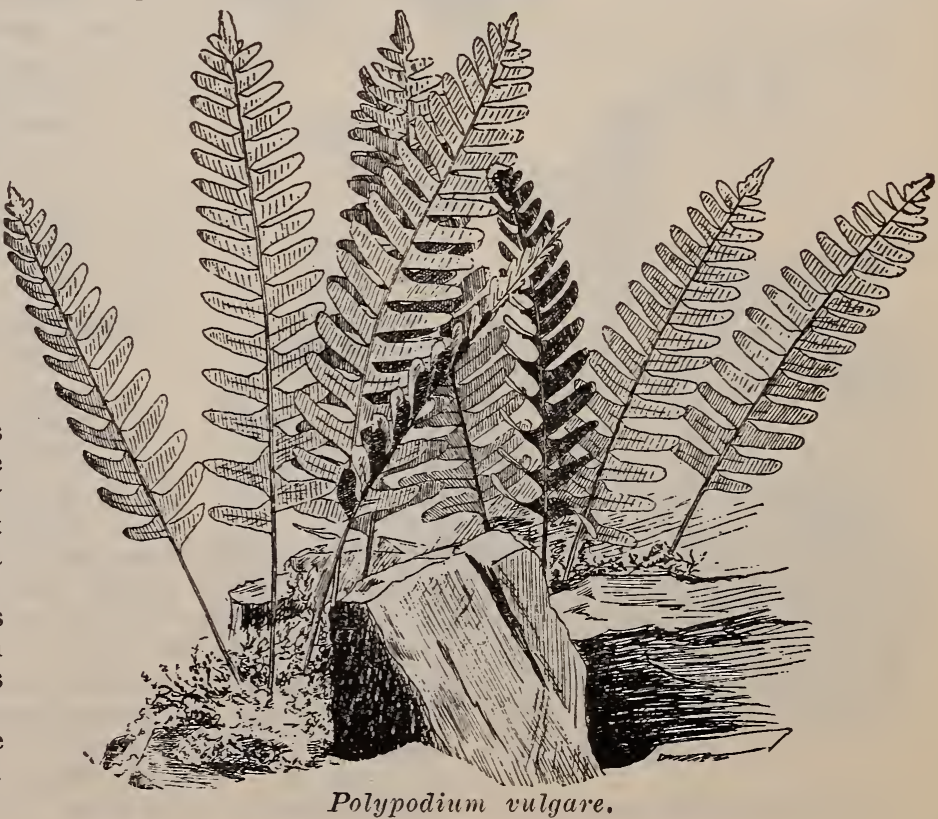


WOODSIA obtusa. Grows from 6 to I2 inches high, with fronds 3 to 4 inches

wide. Found on rocky banks and cliffs. $15 \mathrm{cts}$. each, \$I per doz.

WOODWARDIA (Chain Fern)-

W. angustifolia. 12 to 18 inches high by 3 to 4 inches wide. Grows in wet bogs. 20 cts. each, \$1.20 per doz.

W. Virginica. Is larger, 2 to 3 feet high by 3 to 5 inches broad. Wet swamps or bogs. I 5 cts. each, $\$$ I per doz.

\section{HARDY FERNS.}

The following collections are made up to help in selecting for special needs and should go by express or freight.

\section{No. 1. $\$ 5.00$. For Open Sun Culture.}

This collection is desirable for the open border, and all the Ferns being rather tall can be grown as single specimens or for massing, with or without flowers.

6 Onoclea struthiopteris,

6 Osmunda Claytoniana,
24 Dicksonia punctilobula,

6 Lygodium palmatum.

\section{No. 2. $\$ 5.00$. For Dry, Shady Places.}

These Ferns will grow in a dry, shady place. Plant them where flowers as a rule do not thrive.
12 Aspidium acrostichoides,
12 Dicksonia punctilobula,
12 Aspidium marginale,
12 Osmunda Claytoniana.

No. 3. \$5.00. For Moist, Shady Places. rockery.

This collection is very fine and easily handled in moist, shady places, also for large
6 Adiantum pedatum,
6 Aspidium cristatum,
6 Aspidium acrostichoides,
6 Aspidium spinulosum,
6 Aspidium marginale,

6 Asplenium thelypteroides,

6 Asplenium Filix-fæmina,

6 Phegopteris hexagonoptera,

6 Woodwardia angustifolia.

No. 4. \$5.00. For Wet Open Ground.

These Ferns are very useful for border of a lake or low wet ground.

12 Aspidium Thelypteris,

12 Onoclea sensibilis,
12 0smunda regalis

12 Woodwardia Virginica.

\section{No. 5. \$5.00. Low Evergreen Ferns for Rockery in Shade.}

This is a beautiful collection of low-growing Ferns and easily managed.
12 Asplenium ebeneum,
12 Asplenium Trichomanes,
12 Polypodium vulgare,
12 Camptosorus rhizophyllus,
6 Woodsia obtusa.
No. 6. \$5.00. Low Evergreen Ferns for Dry Rocky Ledge.
12 Asplenium Trichomanes,
12 Cheilanthes vestita,
12 Polypodium vulgare,
12 Woodsia Ilvensis.

\section{One-Half of Any One of the Above Collections for $\$ 3$.}

You will notice that some kinds are named in more than one collection. Such seem to thrive equally well in the localities named. 


\section{Hardy Perennials.}

FLOWERS THAT LIVE YEAR AFTER YEAR.

The prices quoted on these Hardy Perennials are for free delivery in the United States. This does not apply to shrubs

ACHILLEA Millefolium roseum (Rose-Colored Yarrow). This is a fine hardy plant, with rose-colored flowers Plant in a sunny place. ro cts.

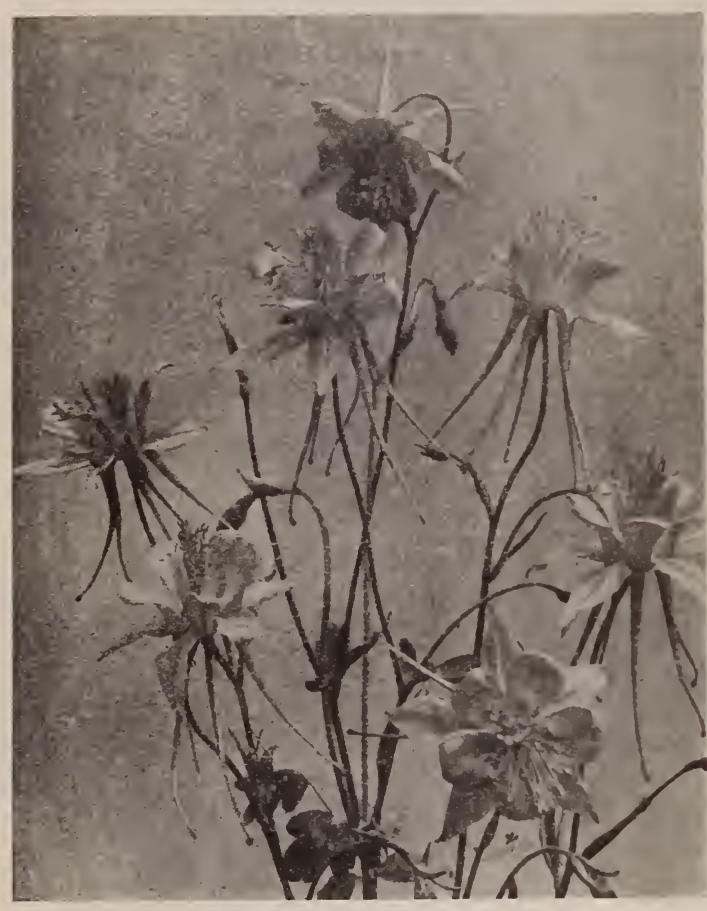

Aquilegia chrysantha.

A, The Pearl. V'ery double pure white flowers in dense, broad heads, all summer. Very choice for cutting. Io $\mathrm{cts}$. each, \$I per doz.

ACTEA alba (White Baneberry). In racemes of white flowers, followed by the white fruit. Fine for rockwork or the shady corner. $15 \mathrm{cts}$.

A.rubra (Red Baneberry). Rather taller than the last, very ornamental in fruit, which is bright red. 15 cts. each, \$1 25 per doz.

AJUGA reptans (Common Bugle). Foliage dark. Used for ribbon borders. $15 \mathrm{cts}$.

ALYSSUM Saxatile compactum (Madwort). Showy perennials with bright yellow flowers in spring. $15 \mathrm{C}$. each, $\$$ I. 50 per doz.

ANEMONE nemorosa (Wind Flower). Grows 2 to 4 inches high. Flowers white, tinged with purple; partial shade. Ioc. each, \$I per doz.

A. Japonica, var. Whirlwind. A tall variety, with large double white flowers, fine for cutting. Forms good clumps; needs protection in winter, not perfectly hardy here. 20 cts.

A. Pennsylvanica. Twelve to 18 inches high, with large single pure white flowers. Plant in the moist border in a sunny place. Quite hardy. Io cts. each, $\$ \mathbf{I}$ per doz.

AQUILEGIA (Columbine). Quite a showy plant, I to 2 feet high, with many varieties and colors of flowers. Loves a moist, sunny place.

A. alpina. From Switzerland. Flowers blue, large and quite showy. May and June. I foot. I 5 cts. each, $\$ 1.35$ per doz.

A. cærulea. From Rocky Mountains. Flowers large, white, tinted with blue in May; rather tender. I5 cts. each, \$I.25 per doz.

A. Canadensis. One of our prettiest wild flowers; 8 to 20 inches high, with yellow and red flowers an inch long. Very desirable for rockeries. Many desire this for the national flower. Io cts. each, $\mathbb{N}$ per doz.

A. chrysantha (Golden-Spurred Columbine). Flowers large, golden yellow, with long spurs. A fine stock. I5 cts. each, \$1.25 per doz.

A. glandulosa cærula. A most beautiful hybrid, with large, light blue flowers having white centers. Easily cultivated. I5 cts.

A. Skinneri. I to 2 feet high, with greenish orange flowers and red spurs. I 5 cts. each, \$I.25 per doz.

A. vulgaris. From Europe. Flowers violet. I 5 cts. each, \$1.25 per doz.

ARABIS albida (Alpine Rock Cress). A low plant, about 6 inches high, with intensely fragrant, pure white flowers; very choice for cutting. I2 cts. each, \$I per doz. 
ARISAEMA triphyllum (Indian, or Wild Turnip). A peculiar-shaped flower; greenish or of ten variegated, found in moist, rich woodlands. I2 cts. each, \$I. IO per doz.

ASARUM Canadensis (Wild Ginger). A low perennial, with kidney-shaped leaves 3 to 5 inches wide, and a single purplish flower close to the ground. Plant in the shady corner with your ferns. Io cts. each, \$I per doz.

ASCLEPIAS incarnata (Swamp Milkweed). 2 to 3 feet high, with showy rose-purple flowers. Grows in wet places and along the banks of streams and ponds. $20 \mathrm{cts}$. each, \$1.25 per doz.

A. tuberosa (Butterfly Weed, or Pleurisy Root). One of the most beautiful and easily grown of our wild flowers. It grows from I to 2 feet high, and has numerous umbels of bright orange flowers. Plant in open sun, in well-drained soil. Hardy. I 5 cts each, $\$$ I.25 per doz.

ASTER. The wild Asters are among our prettiest native flowers. They come late in the season, when most other plants are past their bloom, and last until killed by frosts They are easily grown, and deserve more attention from lovers of wild flowers. Those named are among the most showy of the genus.

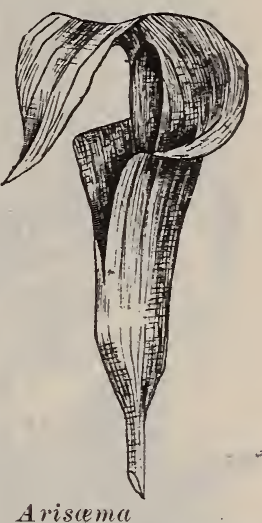

triphyllum.

A. ericoides. Extra fine in cultivation. The graceful, wand-like, spreading branches are literally covered with fine green or purple leaves, and dotted here and there with large white flowers. Plant in dry, sandy soil. I5 cts. each, \$r per doz.

A. Irevis. A beautiful species with sky-blue flowers. Grows in dry woodlands. Io cts. each, \$I per doz.

A. multiflorus. I to 2 feet high; branches covered with small white flowers. Fine for dry open places. Io cts. each, \$1.25 per doz.

A. Novæ-Anglæ. Stout, 3 to 8 feet high. Flowers violet and purple. Moist ground. $20 \mathrm{cts}$. each, \$1.25 per doz.

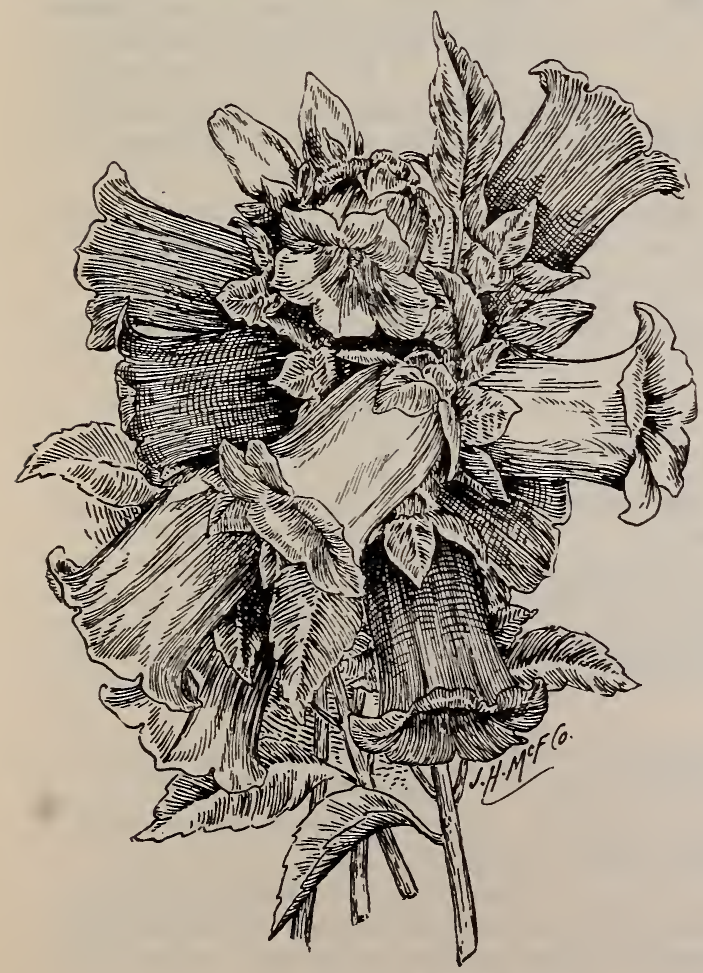

Campanula Medium.
ASTILBE Japonica. I to 2 feet. From Japan. Quite hardy here, forming large clumps. Flowers small, but in white masses in June. At home in the open border. $25 \mathrm{cts}$. each, $\$$ r. 50 per doz.

CALLIRRHOË involucrata (Crimson Callirrhoë). A very beautiful prostrate, spreading perennial from Texas, with large, showy crimson flowers all summer. Fine for the open border or for planting in a dry, barren soil. 20 cts. each, \$I.50 per doz.

CAM PANULA. Plants with showy flowers, mostly in blue, easy to grow and in bloom a long time. For full description see Bailey's Cyclopedia of American Horticulture, pages 226 to 233.

C. alliarizelia. About a foot high, with white, nodding flowers ; suited for open sun culture. $15 \mathrm{cts}$.

C. carpatica. Low plants, forming nice clumps with large blue flowers in summer. Sunny border. I 5 cts.

C. carpatica alba. Like the above, only the flowers are pure white. I5 cts.

C. Medium (Canterbury Bells). I to 2 feet. Flowers large, open, bellshaped, in a variety of color. Biennial. I5 cts. each, \$I.50 per doz. 
CAMPANUlA, Medium. White single. I $5 \mathrm{cts}$.

C. Medium. Double mixed. I 5 cts.

C. pyramidalis (Chimney Campanula). A tall variety, 3 or 4 feet high, with bellshaped blue flowers borne along the upper half of stalk, June and July. Well-

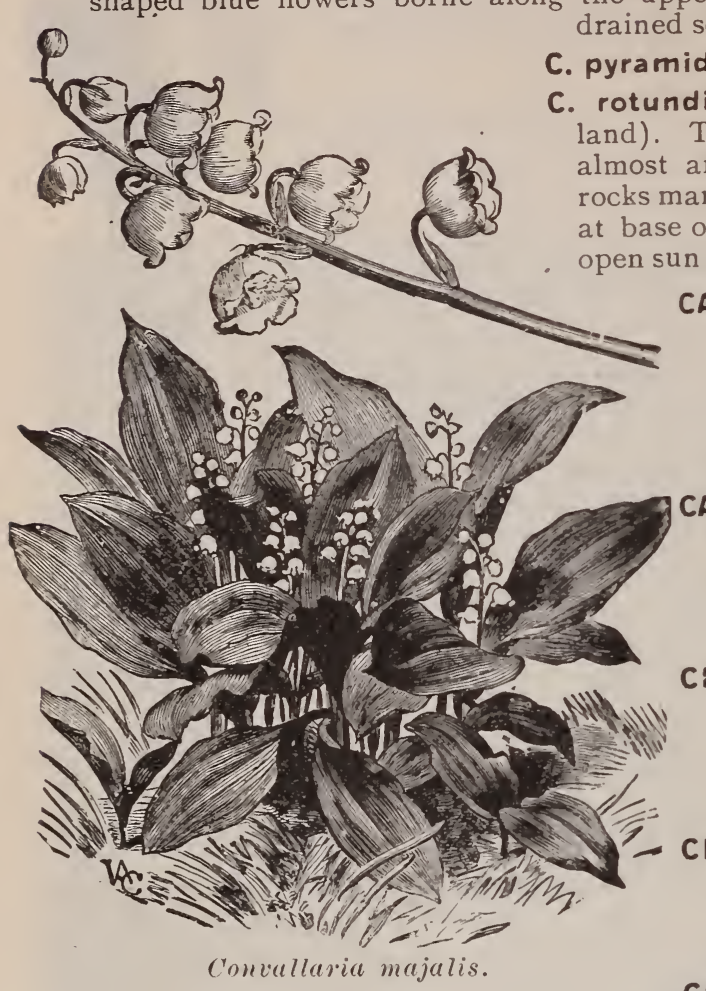

C. pyramidalis alba. White variety of above. I $5 \mathrm{C}$.

C. rotundiflora (Harebell, or Blue Bells of Scotland). This pretty little native will adapt itself to almost any situation. We see it in crevices of rocks many feet above our reach, or along the path at base of mountains. Give it good drainage in pen sun or partial shade. I $5 \mathrm{cts}$. each, \$I per doz.

CASSIA Marilandica (American Senna). A thrifty plant, 2 to 5 feet high, forming large and showy clumps. Flowers yellow, with a dark center. Fine for moist, open places. 10 cts. each, $\$ 1.25$ per doz.

CAULOPHYLLUM thalictroides (Blue Cohosh). A thrifty plant of our rich shady New England hillsides. Flowers greenish, followed by the large blue berries. $20 \mathrm{cts}$.

CHIONODOXA Lucilize (Glory of the Snow). One of the most charming of early spring flowers. Easy of culture and perfect in hardiness. Sky biue. $8 \mathrm{cts}$ each, $50 \mathrm{cts}$. per doz.

CHRYSANTHEMUM maximum. A choice garden plant, easily grown. Flowers white, large and showy. Any soil not too wet. I $5 \mathrm{cts}$. each, \$1.25 per doz.

CIMICIFUGA racemosa (Black Snakeroot). Tall, 4 to 6 feet, with white flowers in elongated racemes. Desirable for a moist, shady corner. I5 cts. each, \$I.50 per doz.

CLAYTONIA parviflora. A fine little plant from Oregon, with a tuft of bright green leaves at the base. Flowers pink on slender stems. Io cts. each, \$I per doz.

Virginica (Spring Beauty). Large rose-colored flowers. Io cts. each, \$I per doz.

CLEMATIS Fremonti. A hardy herbaceous Clematis from Rocky Mountains, growing about a foot high, forming fine clumps. Flowers medium size, blue. $25 \mathrm{cts}$.

CONYALLARIA majalis (Common Lily-of-the-Valley of the garden). Well known in cultivation. Flowers small, white, hell-shaped, very fragrant. $20 \mathrm{cts}$. in clumps, $\$ 1.25$ per doz., \$5 per Ioo.

C., var. "Miellez's Revelation" in Lily-of-the-Valley. It is of extraordinary size and vigor, of the most exquisite fragrance and does well under all conditions and all sorts of soils, growing just as well in full sun as partial shade. Extremely hardy and while not increasing quite so fast as the common kinds is still of good increase. It is well to cover it in December with a good coat of barnyard manure; green is just as good as old. Leave it in the spring to serve as mulch. The Massachusetts Horticultural Society awarded it a "First-Class Certificate of Merit," May 22, I897. I 5 cts each, \$r.50 per doz.

COPTIS trifolia (Goldthread). A little low evergreen, with bright shiny leaves and white flowers. Plant in a moist, shady place. Io cts. each, \$I per doz.

COREOPSIS lanceolata. Grows I to 2 feet high, with large showy yellow flowers. Rich, damp soil. Io cts. each, \$I per doz.

CORNUS Canadensis.(Dwarf Cornel). Plant 6 inches high, with four broad leaves at the top. Flowers greenish, surrounded by a showy white involucre, followed by bright red berries. Desirable for a shady corner. Fine for massing. I $5 \mathrm{cts}$. each, \$I 50 per doz. 


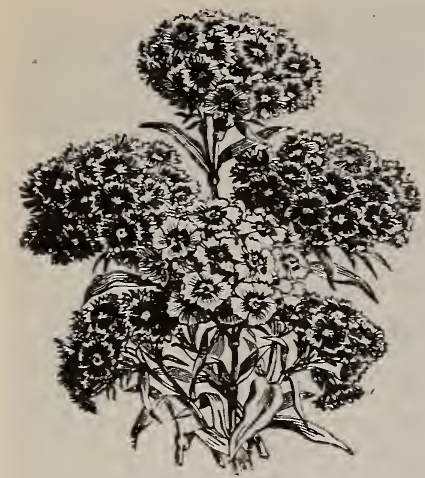

Dianthus barbatus.

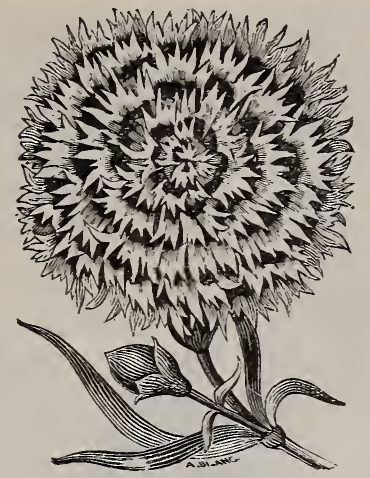

Dianthus, Mr.s. Simkins.

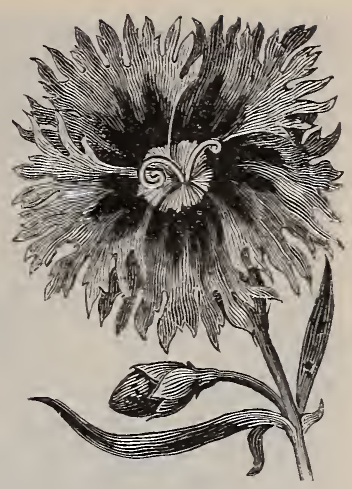

Dianthus plumarius.

CYNTHIA Virginica. A foot high, with heads of showy yellow flowers. Moist soils. Ioc.

DELPHINIUM (Larkspur). The Larkspurs when well grown are among the choicest of our garden plants. They require a light and well-drained soil and respond to good cultivation. The tall varieties can be grown 6 to 8 feet, and make fine backgrounds for lower-growing sorts.

D. formosum. Tall-growing species, 6 feet or more, with great spikes of flowers in a variety of shading from almost pure white to dark blue or purple. $25 \mathrm{cts}$. each, \$1.50 per doz.

D. grandiflorum. Low-growing, with finely cut leaves, the large and graceful flowers in an almost endless variety of blue, from almost pure white to finest tints of dark blue, all summer. Io cts. each, \$I per doz.

D. grandiflorum album. Pure white or very light tints. $15 \mathrm{cts}$.

DENTARIA diphylla (Tooth-Wort, or Pepper-Root). Six to 15 inches high, with a single corymb of pretty white flowers. May. Io cts. each, $\$$ I per doz.

DIANTHUS (Pink). The garden sorts are of easy culture in rich, well-drained soil. They are for the most part low-growing; some are very fragrant. The family contains nearly all the desirable colors.

D. barbatus (Sweet William). These are among the very brightest of our hardy plants, growing about a foot high, with long green leaves and bearing on top the large heads of bright flowers in great variety of color. I 5 cts. each, $\$ 1.25$ per doz.

D. barbatus fl. pl. Double varieties of the above. I 5 cts.

D. deltoides (Maiden Pink). A little prostrate pink, with fine pointed leaves. Flowers deep red, with crimson eye. Summer. I5 cts. each, \$1.25 per doz.

D., var. Napoleon III. A hardy Carnation of healthy and vigorous growth, forming fine large clumps. The double, bright crimson fragrant flowers are supported on straight, firm stems and flower through the season. I5 cts. each, $\$ 1.50$ per doz.

D. plumarius (Grass, or Garden Pink). A very hardy single Pink that flowers in many colors. Plant in light soil. I 5 cts.

D., var. Her Majesty. A large, pure white Pink that is very fragrant and forms large clumps. Summer. Hardy. 25 cts.

D., var. Mrs. Simkins. Similar to Her Majesty. The flowers are not so large, but more abundant. Fragrant and quite hardy everywhere. I5 cts.

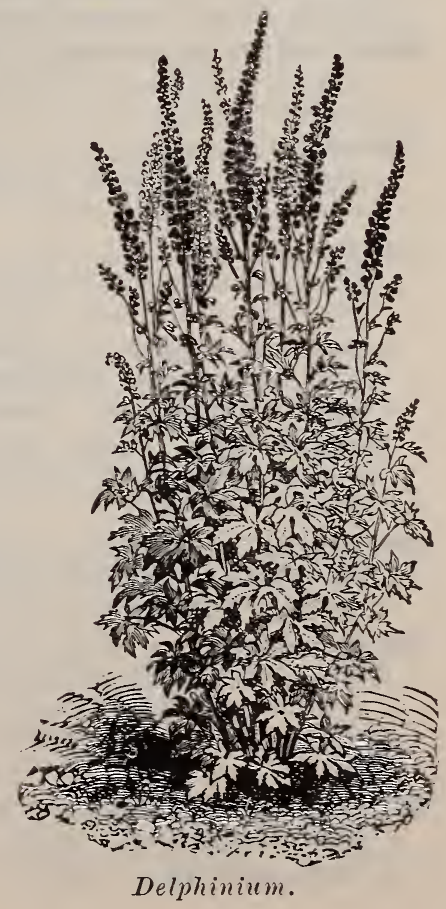

Delphinium. 
DIGITALIS purpurea (Foxglove). In mixed colors. Fine plants. Io cts, each, 75c. per doz

DICENTRA cucullaria (Dutchman's Breeches). A very early spring flower, with delicate, divided leaves. Grows about 8 inches high. Greenish white flowers tinged

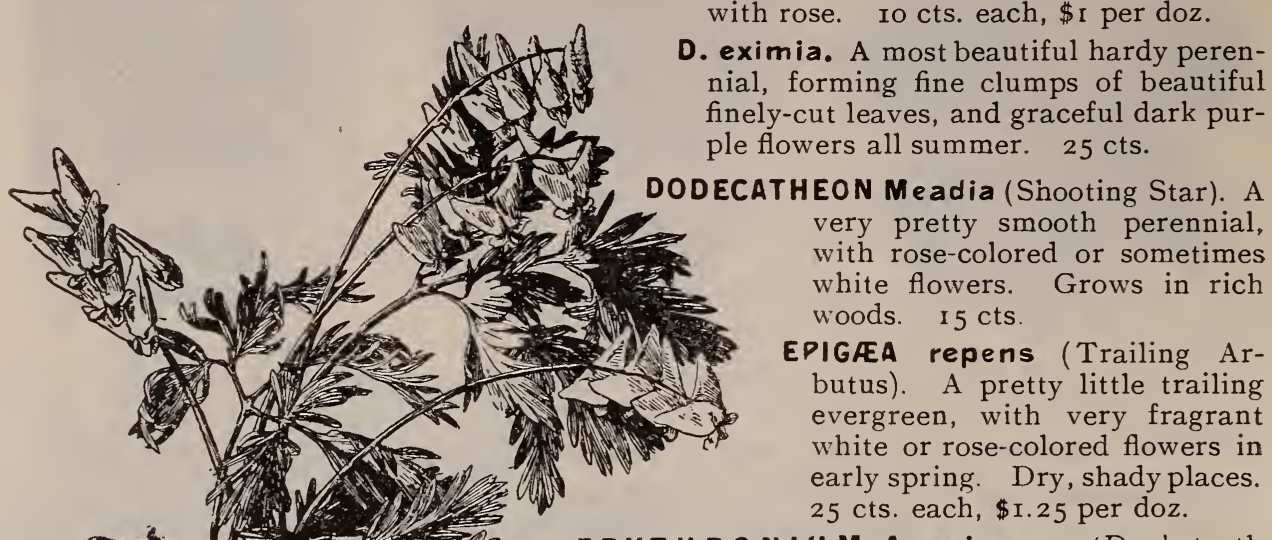

ERYTHRONIU M Americanum (Dog's-tooth Violet). This plant is often called Adder's Tongue. It grows about ro inches high, bearing in early spring bright yellow, lily-like flowers about an inch broad The bulb should be placed 6 inches below the surface. A beautiful plant. Io cts. each, $\$$ I per doz.

ECHINACEA purpurea (Purple Cone-Flower). Desirable Dicentra cucullaria. for a dry, exposed position. Flowers large, purple, on stalks 2 to 3 feet high. 20 cts.

EULALIA Japsnica, var. variegata. A beautiful variegated-leaved grass, growing 4 feet or more. 25 cts.

Japonica, var. zebrina (Zebra Grass). The markings run crosswise of the leaf, giving a very strange appearance. $25 \mathrm{cts}$.

EUPATORIUM ageratoides (White Snakeroot). 2 to 3 feet high, with a profusion of small white flowers, in heads, in late summer. Very desirable for cutting. ro cts. each, \$I per doz.

EUPHORBIA corollata (Flowering Spurge). A hardy, branching perennial, 2 to 3 feet high, with pure white petal-like bracts around the true flower. Fine for cutting. I 5 cts. each, \$I per doz.

FUNKIA grandiflora (Day Lily). Showy light green foliage, and clusters of pure white fragrant flowers. One of the very choicest plants. $20 \mathrm{cts}$.

F. aurea variegata (Variegated-Leaved Day Lily). The leaves are beautifully variegated with white. Very hardy. Clumps. 25 cts.

Thomas Hogg. Foliage banded with clear white. A very choice variety, with large purplish lilac flowers. $20 \mathrm{cts}$.

GAILLARDIA grandiflora. Large yellow and red flowers on stems a foot high, shaped like an oxeye daisy ; showy. I5 cts.

GALAX aphylla. A pretty little evergreen, with shining red or green leaves. From mountains of North Carolina. Stalk a foot high, bearing many small white flowers. I5 cts. each, \$1.50 per doz.

GALEGA officinalis. Blue. Thrifty perennials, with pea-shaped flowers. Io cts.

G. officinale alba. White. Io cts.

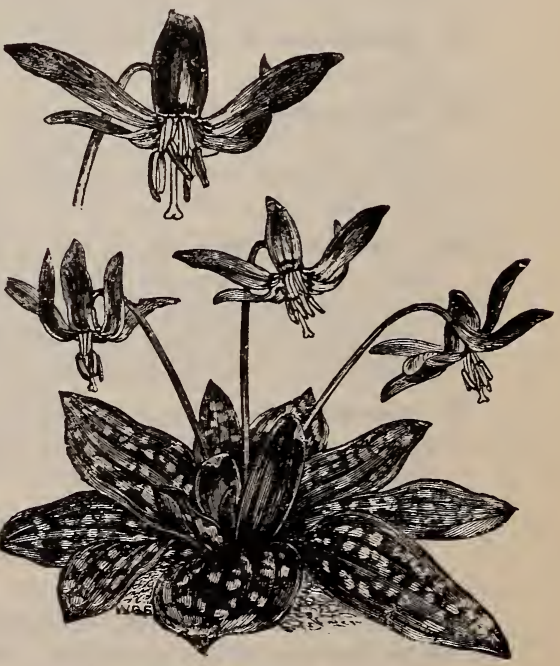

Erythronium Americanum. 


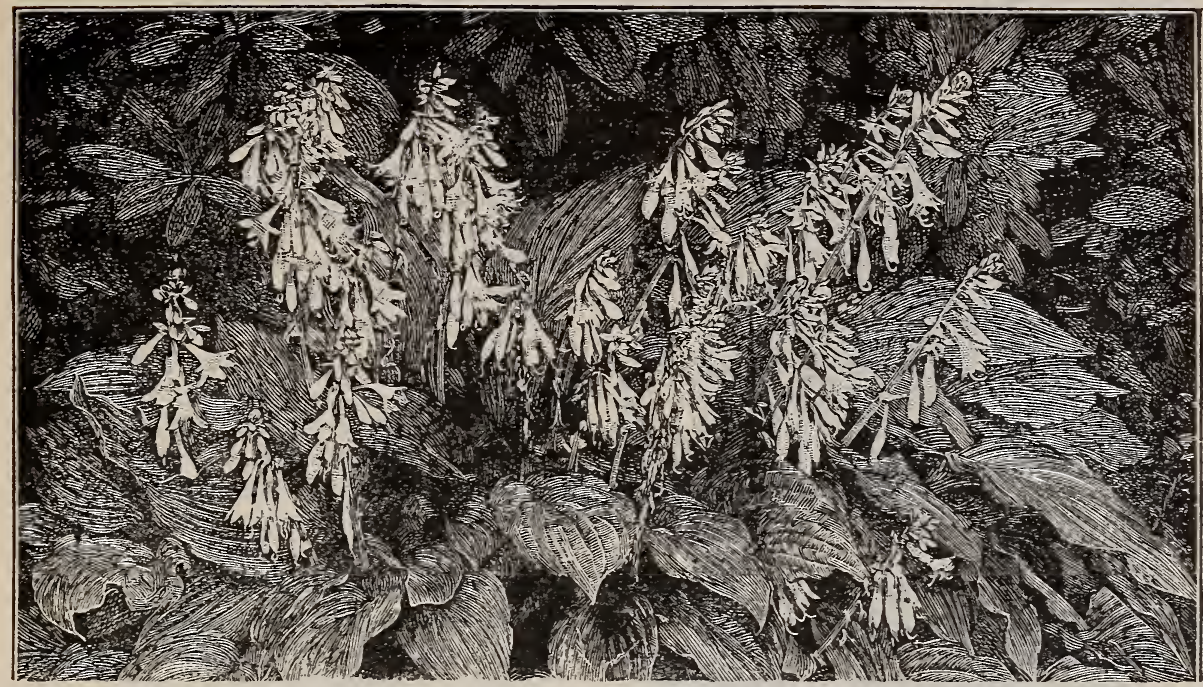

Funkia, or Day Lily. (See preceding page.)

GAULTHERIA procumbens (Aromatic Wintergreen). A low evergreen, with bright green leaves. Flowers white, followed by the bright red berries, which remain until the next season. $20 \mathrm{cts}$, each, \$1.25 per doz.

GENTIANA Andrewsii (Closed Gentian). A pretty and strong-growing northern species, with clusters of blue flowers an inch or more in length. Plant in rich, moist soil. I 5 cts. each, \$I per doz.

GERANIUM Robertianum (Crane's Bill). This little biennial is pretty for rockeries. It begins blooming in June and continues until October. Leaves strong-scented; flowers small, red-purple. Moist soil. Io cts. each, \$I per doz.

G. maculatum (Wild Crane's Bill). I 5 cts. each, \$I per doz.

GYPSOPHILA paniculata (Infant's Breath). Flowers very small, in open panicles with stiff wiry stems. Beautiful, and much used in all flower-work where white flowers are needed. 3 feet. I 5 cts.

HELIANTHUS decapetalus. A fine species with bright yellow flowers in broad heads. 3 to 5 feet. 20 cts.

HEUCHERA sanguinea (Coral Bells). Leaves evergreen, scalloped and marbled. Flowers borne on long stems, small, but of the most brilliant scarlet. $20 \mathrm{cts}$. each, $\$$ I. 50 per doz.

HEM EROCALLIS flava. Flowers large, open bell-shaped, clear yellow. Very fragrant. Forms large clumps. 2 feet. I 5 cts. each, \$I.50 per doz.

HEPATICA triloba (Round-Lobed Hepatica). One of the earliest of our wildwood flowers. Leaves three-lobed; flowers vary from pure white to all shades of pink and dark purple. Fine for massing in the shady corner or open woods Io cts. each, \$I per doz., \$5 per Ioo.

HIBISCUS moscheutos rosa (Swamp Rose Mallow). A tall, thrifty plant, desirable for a moist, sunny place. Flowers large, rose-colored, and very showy. I 5 cts. each, \$I per doz.

H., Crimson Eye. Flowers large, pure white, with deep crimson eye. Very choice and new. Perfectly hardy either in common garden soil or very wet places. I5 cts. each, \$I.50 per doz.

HOLLYHOCKS (Althcea rosea). Double, in separate colors, pink, canary-yellow, crimson, white and salmon. I5 cts.

HOUSTONIA carulea (Bluets). A little low biennial, 2 to 4 inches high, sparingly branched from the base. Flowers small, delicate light blue, sometimes pale lilac or white, with a yellowish eye. Grows in tufts in open moist or grassy places. May. Io cts. each, \$I per doz.

H. purpurea. 2 to 6 inches high, with waxy white flowers all summer. At home in the rock garden. I5 cts. each, \$I per doz. 
HYDRASTIS Canadensis (Orange Root). 4 to ro inches high, sending up in early spring a stem, two-leaved at the top, terminated by a greenish white flower, fol-

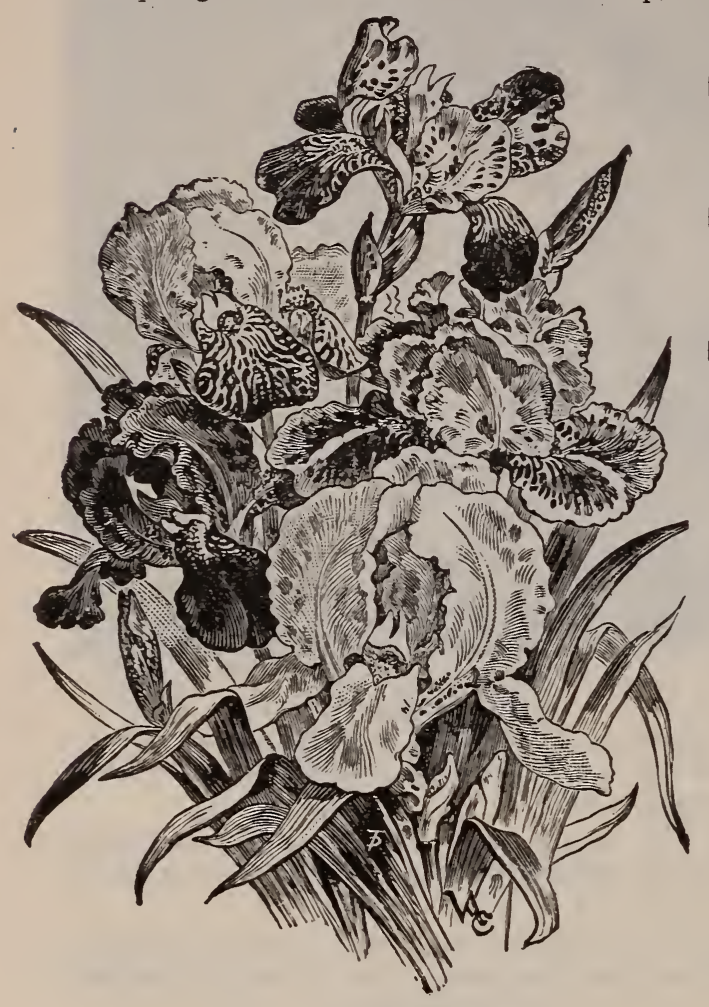

Irois Germaniea. lowed by red berries. Moist shades. Rare. Io cts. each, \$I per doz.

HYPOXIS erecta (Star Grass). A little wood plant, with grass-like leaves, and rather large yellow flowers. Io cts. each, \$I per doz.

IBERIS sempervirens (Candytuft). From Canada. Quantities of pure white flowers. One of the choicest for cutting. Hardy. I 5 cts. each, $\$$ I. 25 per doz.

IRIS cristata. From the south. A lowgrowing kind, with blue flowers marked with white. Io cts.

I. pumila (Dwarf Iris). Deep purple flowers. Very hardy. Io cts. each, $\$$ I per doz.

1. pumila alba. A white variety. Ioc.

I. pumila sulphurea. Yellow. Io cts.

I. Sibirica. A tall species, with small blue or white flowers. Fine. Ioc. each, \$I per doz.

I. tenax (Tough-Leaved Iris). Flowers purple with white blotches; leaves narrow. I 5 cts.

I. versicolor. About 20 inches high, with pretty blue and white flowers. Grows in wet places and along brooksides. Io cts. each, \$I per doz.

I. Virginica. A species from near the coast. Flowers blue and white. More slender than the former. Io cts. each, $\$$ I per doz.

IRIS Germanica (German Iris). This beautiful and varied Iris will thrive in almost any situation, yet it delights in a moist soil. Just above the water in a lake it sets off other plants to advantage. Colors ranging from yellow, white, red, blue, purple, etc.

Yellow, White, Purple and Blue. $20 \mathrm{cts}$. each, \$I 25 per doz.

Mixed colors. \$I per doz.

IRIS Kampferi (Japan Iris). This large and beautiful Iris is perfectly hardy, a great bloomer, and is becoming very popular for planting in moist situations, yet it will flower in almost any place. The flowers are from 6 to 8 inches across, and nearly all the rainbow colors are here represented in gorgeous coloring and soft-tinted shading, coming to perfection in June and July. Pure white shading to pink, purple and blue, deep indigo and yellow, with markings and splashes indescribable. Below are given some fine named sorts in nice clumps.

\section{IRIS KAEMPFERI VARIETIES.}

Arthur Silbard. Single white, veined lilac. Late.

Dictator. Single, deep purple.

Gloriosa. Double, deep blue.

Gold Bound. Pure white.

J. C. Vaughan. White.

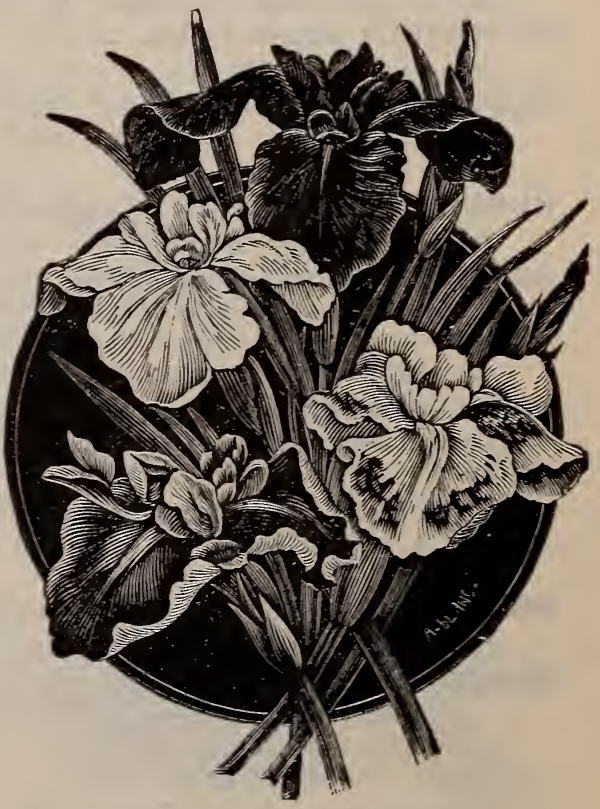

Iris Kumpferi. 
Iris Kaempferi Varieties, continued.

Robert Craig. Very large, white veined velvet, deep velvet center.

Romeo. Deep maroon. Fine.

Tokio. Semi-double, blue, veined with white.

25 cts. each, $\$ 2$ per doz., for any of the above; seedlings of above Japan Iris, mixed, 3 years, 75 cts. per doz., $\$ 4$ per 100.

IRIS verna. A small, crested yellow species from the mountains of North Carolina. I $5 \mathrm{cts}$. each, \$I per doz.

LIATRIS (Blazing Star). Very pretty border plants, thriving in light, well-drained soil. They have long grasslike foliage and showy purple flowers in heads or spikes, sometimes 3 feet long.

L. graminifolia. A very beautiful plant, about a foot high, with a delicate spike of small purple flowers. r 5 cts. each, \$I.25 per doz.

L. pycnostachya (Kansas Gay Feather). A beautiful species from the western prairies. Spike of flowers often 3 feet long. Desirable for the open border. Io cts. each, \$I per doz.

L. scariosa (Button Snakeroot). 2 to 5 feet high, with large heads of rose-purple flowers in late summer. Rich soil. Io cts. each, \$I per doz.

L. spicata (Spiked Blazing Star). Flowers rose-purple

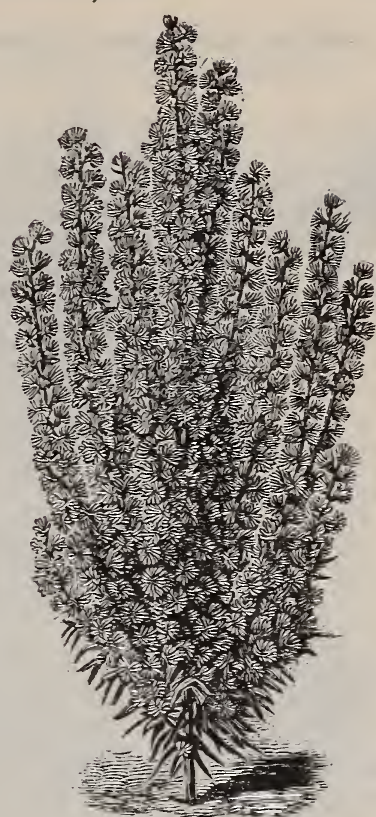

Liatris (Blazing Star). in a long spike; blooms with the last. Io cts. each, \$I per doz.

LILIUM auratum (Golden-Rayed Lily of Japan). A large and beautiful species with a white groundwork, little points of crimson all over the inner face, and a narrow band of gold painted along the center of each petal. Very fragrant and hardy. I can supply nice large bulbs at I5 cts. each, \$I.5O per doz.

L: candidum (Annunciation Lily). A most beautiful and fragrant Lily, well known in cultivation. A thrifty grower, delights in a light, sandy soil, and is sure to repay the care we devote to it. Hardy. Io cts. each, \$I per doz.

L. elegans (Thunbergianum). Extra fine red. I5 cts. each, \$I.50 per doz.

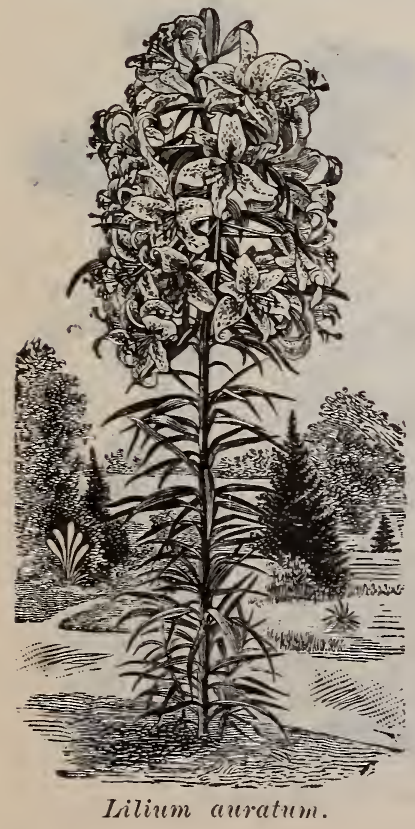

L. Canadense (Wild Meadow Lily). Grows 2 to 4 feet high, with one to many yellow or yellowish red flowers. Moist clay or sandy soil, well enriched. ro cts. each, \$I per doz.

L., var. rubrum. Has red flowers. A fine Lily. I 5 cts. each, \$I.25 per doz.

L., var. flavum. Has yellow flowers. I5 cts. each, $\$$ I.25 per doz.

L. Philadelphicum (Wild Orange-Red Lily). I to 2 feet high, with upright I to 2 open bell-shaped flowers, reddish orange spotted with purple. Plant in a well-drained soil. I 5 cts. each, \$I per doz.

L. superbum (The Superb Orange Lily). A very fine native Lily, from 4 to 8 feet high, with flowers from 5 to 50 on a stalk. It is a great feeder and requires lots of fine manure, in a soil 2 to 4 feet deep. Io cts. each, \$I per doz.

LATHYRUS latifolius (Perennial Pea). Similar to the sweet pea in appearance but has no fragrance. The flowers are purple and quite large and showy. Plant it with some support to climb over. $25 \mathrm{cts}$.

L. Iatifolius alba. Pure white flowers. $25 \mathrm{cts}$.

Especial attention is called to my lists of FERNS and IRIS which contain all the more satisfactory varieties. 
LOBELIA cardinalis (Cardinal Flower). One of the showiest of our wild flowers, 2 to 4 feet high, with large deep red blossoms along the upper part of the stalk; will thrive

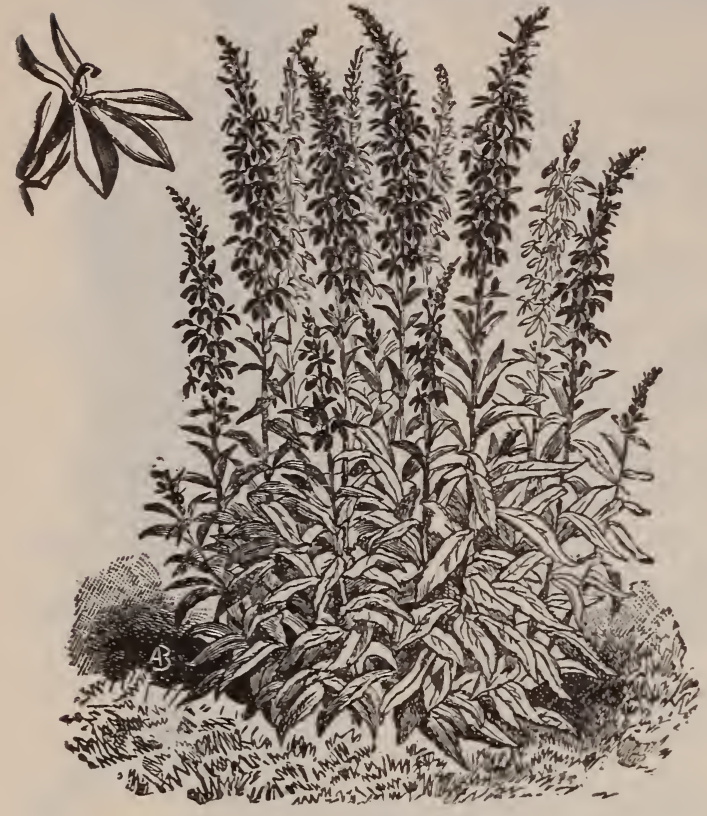

Lobetia cardinalis. in any garden soil or along the border of a lily pond, in water 2 or 3 inches deep. Io cts. each, \$I per doz, \$5 per 100

L. syphilitica (Great Blue Lobelia). Similar in growth to the last, but the flowers are blue, streaked with white. Plant in a moist place Desirable for border of brook or lake. Io cts each, \$I per doz.

LYCHNIS. A class of hardy plants well deserving a place in the garden. Not tall but quite showy.

L. Chalcedonica. Flowers scarlet ; plant in rich soil. June. 2 feet. 5 cts. each, \$I 50 per doz.

L. Chalcedonica alba. Flowers white. I 5 cts.

L. Hageana. Plant 8 to 12 inches high, with large scarlet flowers. Rich borders. I 5 cts.

L. Haageana grandiflora alba. I 5 cts.

L. viscaria splendens (Ragged Robin). A low-growing pink-flowered plant, quite desirable for edgings. I5 cts. each, \$1.25 per doz.

LYTHRUM roseum superbum. Rose-purpleflowers; grows along margins of streams. IO cts.

MERTENSIA Virginica (Virginia Cowslip). This plant grows from I to 2 feet high, bearing a panicle of rich purple or sometimes white flowers. I5 cts. each, \$1.25 per doz.

MITChELLA repens (Partridge Berry). A little trailing evergreen. It forms fine mats under evergreens, and when once established is sure to please $25 \mathrm{cts}$. each, $\$ 1.50$ per doz.

MITEllA diphylla (Bishop's Cap). Grows I to 2 feet high, producing in early spring racemes 6 to 8 inches long, of delicate white flowers Pretty for rockeries. IOc. each, \$I per doz.

MONARDA didyma (Oswego Tea). 2 to 3 feet high, with bright red flowers. Forms very fine clumps. I5 cts. each, $\$$ I per doz.

myosotis palustris (Forget-Me-Not). Lovely light blue flowers with yellow centers. Its home is in wet, springy places, yet it does fairly well in the moist border. Io cts. each, $\$$ I per doz.

NARCISSUS alba plena. Io cts. each, $50 c$. per doz

N. Figaro. Io cts. each, 75 cts. per doz.

N. totus albus. Io cts. each, 5oc. per doz.

N. poeticus. $5 \mathrm{cts}$. each, $35 \mathrm{cts}$. per doz., $\$ 1.50$ per IOO.

N. von Sion. Io cts. each, $60 \mathrm{cts}$. per doz.

CNOTHERA Missouriensis. A low plant,
with very large yellow flowers. Quite showy and interesting; blooms profusely and is always admired. I 5 cts.

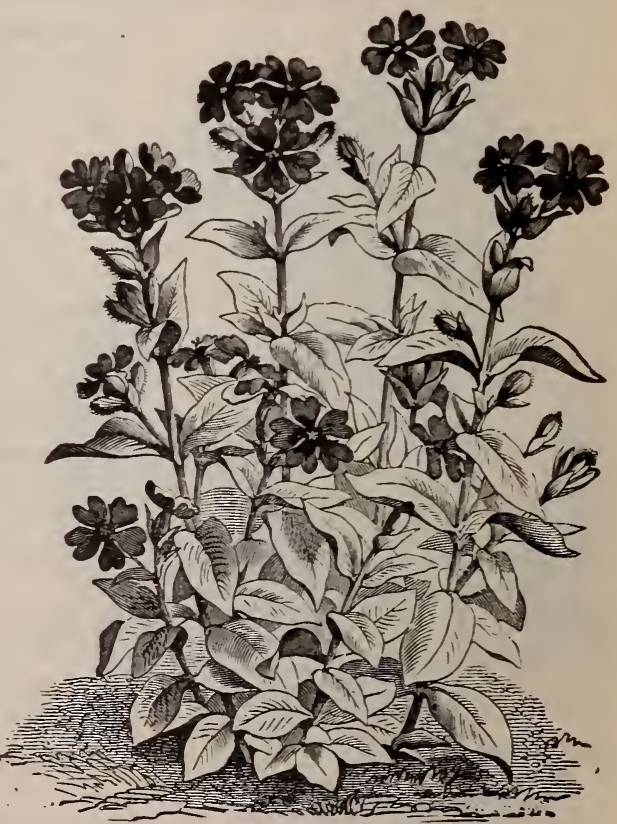

Lychnis Haageana. 
OXALIS acetosella (Wood Sorrel). A beautiful Oxalis found growing in moss in shady moist places. Flowers large, white with purple veins. Io cts. each, $\$$ I per doz.

0. violacea (Violet Wood Oxalis). 2 to 6 inches high, from a scaly bulb. Flowers pink; fine dark foliage. I 5 cts.

PARNASSIA Caroliniana (Grass of Parnassus). 6 to I5 inches high. Flowers white. I5 cts. each, \$I per doz.

PANSY PLANTS. Fine, thrifty, field-grown plants from the very choicest seed. Mixed colors, 5 cts. each, 35 cts. per doz.; by express, $25 \mathrm{C}$. per doz., \$I.75 per roo.

PHLOX divaricata. About $\mathrm{I}_{5}$ inches high. Flowers pale lilac or bluish. Grows in rocky woods. ro cts. each, \$I. Io per dozen.

P. maculata (Wild Sweet William). I to 3 feet high, with white or purple flowers. Io cts. each, \$I per doz.

P. subulata (Ground or Moss Pink). A creeping or tufted species, growing in broad mats on dry, rocky hills or sand-banks. Flowers pink, purple or rose color, with a dark center. Io cts. each, \$r. ro per doz.

P., subulata var. alba. A variety of the above, with

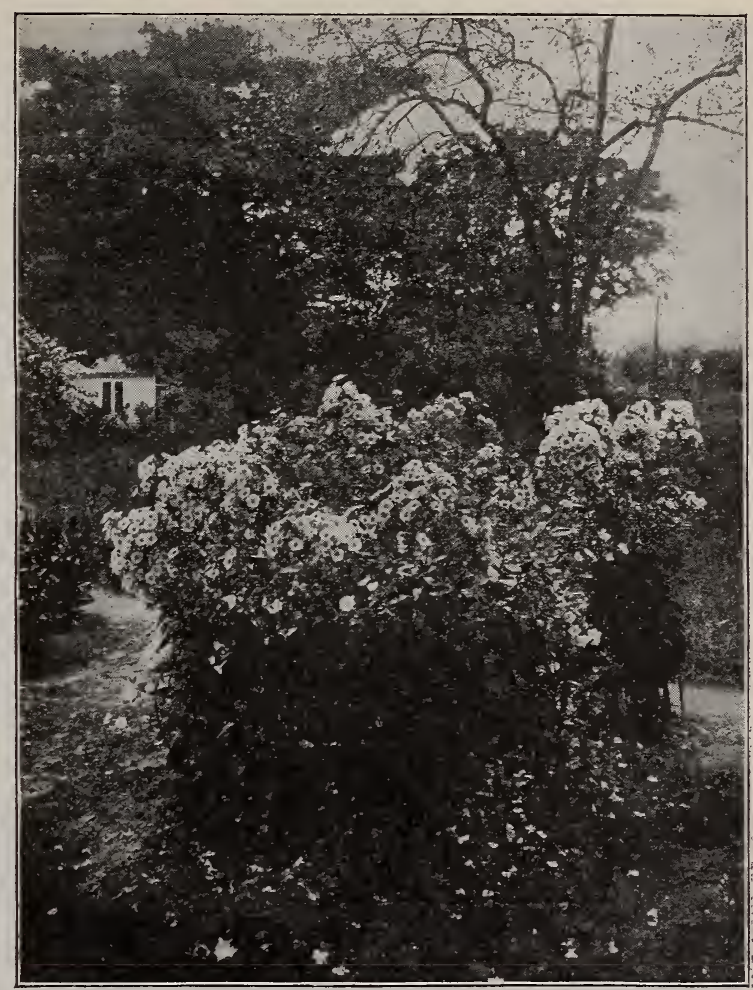

A Clump of Hardy Perennial Phlox. pure white flowers. It is very desirable for covering a rocky or sandy place. I $5 \mathrm{cts}$. each, \$1:25 per doz.

P. reptans. A low plant, with large rose-purple flowers. I $5 \mathrm{cts}$. each, \$I.Io per doz.

P. var. La Pole Nord. A hybrid Phlox having pure white flowers, with very distinct crimson eye. Tall and one of the choicest late bloomers. $25 \mathrm{cts}$.

PLATYCODON Mariesi. Beautiful species with dark green foliage and large, deep violet-blue flowers, 2 to 3 inches in diameter. Very choice. I foot. Large clumps. 25 cts.

PODOPHYLLU M peltatum (May Apple, or Mandrake). A perennial herb, with creeping root-stocks and fibrous roots. Grows a foot or more high, with large, round 7to 9 -lobed leaves, peltate in the middle. Flowers nodding, white, I to 2 inches

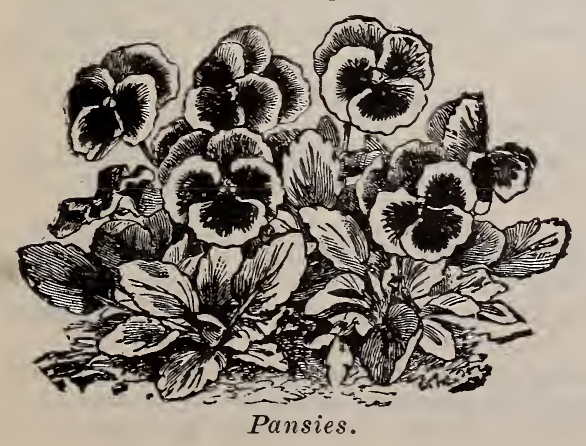
broad. I5 cts. each, $\$$ I. 25 per doz.

POLEMONIUM reptans (Greek Valerian). Finely cut foliage and clear blue flowers in clusters. Fine. roc. each, $\$$ r per doz.

POLYGALA paucifolia (Fringed Polygala). A low-growing and interesting plant. Leaves of a delicate purple tint, large and handsome rose-purple flowers, beautifully fringed. I 5 cts. each, \$r.50 per doz.

P. senega (Seneca Snakeroot). This plant has two or more stems from a thick rootstalk. Grows 6 to 12 inches high, bearing a raceme or spike of small white flowers. I 5 cts. each, \$I Io per doz. 
PYRETHRUM hybridum (Feverfew). Popular flowers, deserving a place in every garden. The plant forms broad clumps, with handsome fern-like foliage. $25 \mathrm{cts}$.

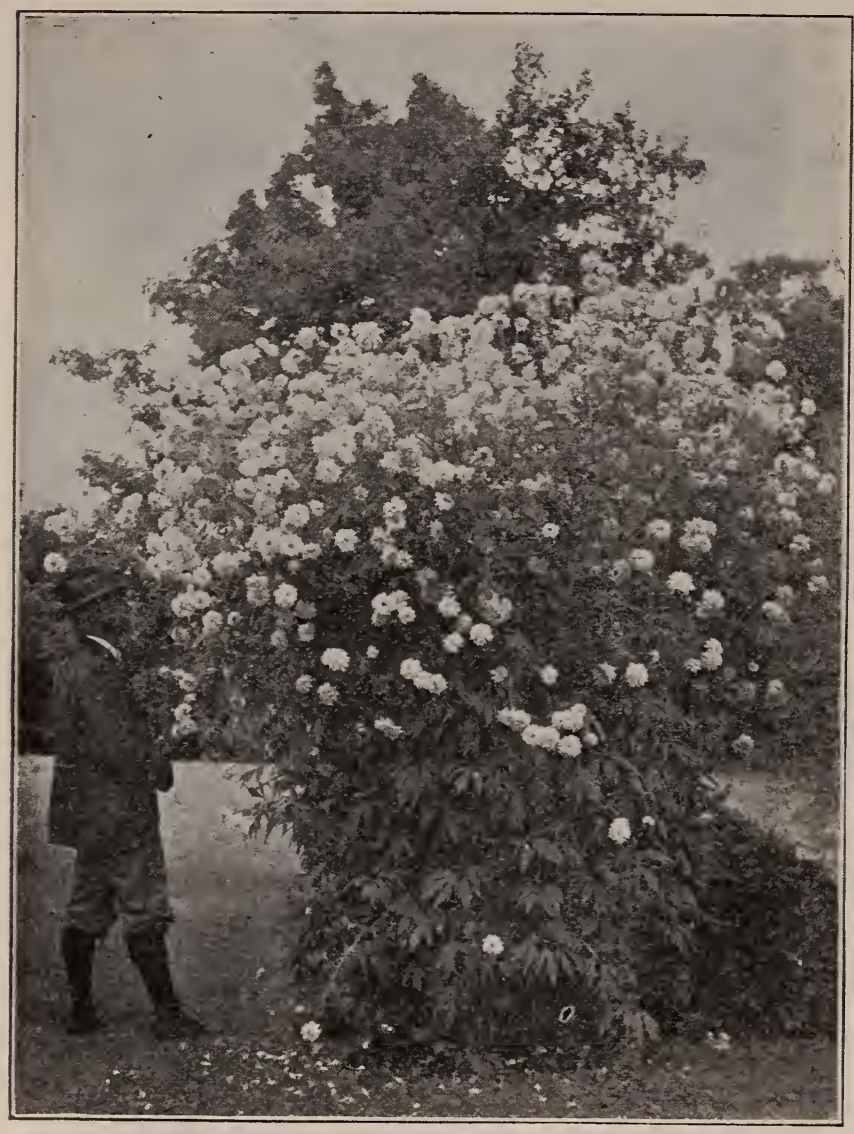

Rudbeckia lanceolata.

P. uliginosum (Great $\mathrm{Ox}-\mathrm{Eye}$, or Giant Daisy). 2 to 3 feet. Russia. One of the choicest. Forms a stout, upright bush, with light green foliage. In autumn it bears a profusion of the choicest pure white flowers, with bright yellow centers. 2 to 3 inches across. $25 \mathrm{cts}$.

RHEXIA Virginica (Meadow Beauty). A low perennial, less than a foot high, with numerous bright purple flowers and yellow stamens. Plant in the open border. I 5 cts. each, \$I per doz.

\section{RUDBECKIA lanceolata}

(Golden Glow). A very showy plant, with very large double yellow flowers. Forms fine clumps; blooms in late autumn. I5 cts.

SANGUINARIA Canadensis (Bloodroot). A low perennial, about 6 inches high, with pure white flowers, an inch in diameter, in early spring. The large, leathery leaves appear later. Plant in the border or rock garden. I5 cts. each, \$I.25 per doz., \$5 per Ioo.

SAXIFRAGA Virginiensis. A low perennial, 4 to 9 inches high, with a cluster cyme of pretty white flowers, appearing in early spring. Pretty for rockeries. Io cts. each, \$I per doz.

S. cordifolia. From Siberia. Flowers rose-colored, in early spring. Leaves rather large, quite near the ground. 25 cts.

SEDUM acre. A little low tufted perennial, spreading on the ground. Flowers yellow, very pretty for rockwork. $8 \mathrm{cts}$. each, $75 \mathrm{cts}$. per doz.

SHORTIA galacifolia. A rare and beautiful species but recently introduced from the mountains of North Carolina. The leaves are evergreen, the petals, 5 in number, are pure white and scalloped or notched on the edges; flower about an inch across. Hardy. 25 cts. each, $\$ 3$ per doz.

SILENE Pennsylvanica (Wild Pink). Low, 5 to 8 inches high. Flowers clustered, short-stalked, pink. I5 cts. each, \$I. Io per doz.

P. Virginica (Fire Pink). Delights in a well-drained soil and when well grown is about a foot high, well branched and bearing large crimson flowers. Try it. I5 cts. each, \$1.25 per doz.

SOLIDAGO (Goldenrod). This is an attractive genus of plants, with a large number of variable species, some of which are very beautiful. They come into flower a little before the asters and with them add much to the bloom in autumn. In mixed sorts. Io cts. each, \$I per doz.

S. odora (Sweet Goldenrod). This species grows about 2 feet high. Leaves bright green, having a sweet aromatic taste and an odor like anise. Flowers of a darker yellow than in most species. Dry shady places. I5 cts. each, $\$ \mathrm{r} .25$ per doz. 
STREPTOPUS roseus (Twisted Stalk). 6 to 20 inches high. Flowers small, rosepurple. Grows in cool damp woods. $20 \mathrm{cts}$. each, $\$ \mathrm{I} .25$ per doz.

THALICTRUM (Meadow Rue)-

T. anemónoides (Rue Anemone). This plant grows about 9 inches high, from a cluster of thickened tuberous roots. Flowers in umbels, white. I5 cts. each, \$I per doz.

T. dioicum. I' to 2 feet, with purple or greenish flowers. I5 cts. each, \$I. Io per doz.

T. cornuti (Tall Meadow Rue) 4 to 8 feet high, bearing a compound panicle of white flowers. Wet meadows. I $5 \mathrm{cts}$. each, \$I.25 per doz.

TIARELLA cordifolia (False Miterwort). About ro inches high, bearing a short raceme of pretty white flowers. Io cts. each, \$I per doz.

TRADESCANTIA Virginica (Spiderwort). An old garden plant, well known for its long grass-like leaves and blue or violet flowers. $20 \mathrm{cts}$. each, \$1.25 per doz.

TRILLIUM (Three-leaved Nightshade). A class of low perennials, having

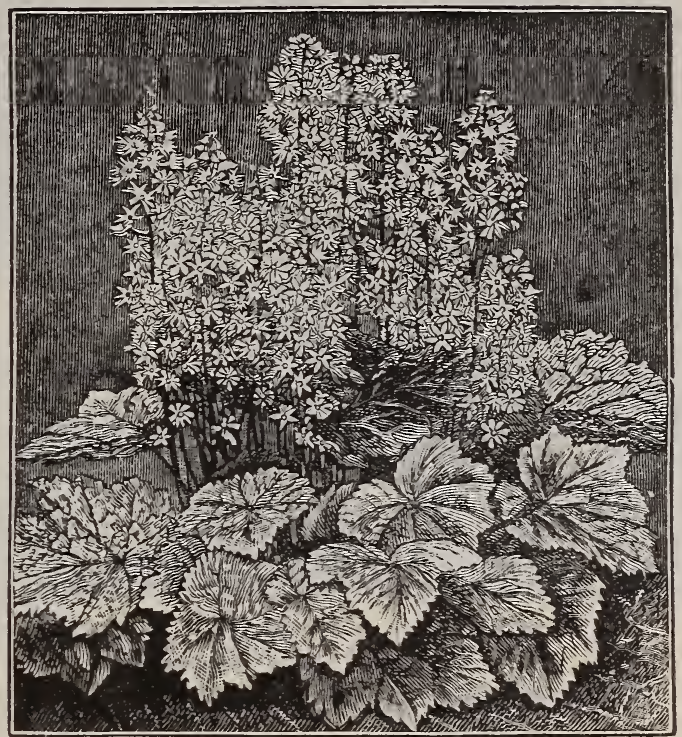

Tiarella cordifolia. a stout and simple stem from a tuber-like root, naked, and bearing at the top three ample leaves in a whorl and a terminal flower. They belong to the lily family, bloom in early spring, and are easily grown. They like a moist, shady situation.

T. cernuium. Is about a foot high, with nodding white flowers tinted with purple Io cts. each, \$I per doz.

T. grandiflorum. Probably the prettiest of the genus, and most generally cultivated. It grows 8 to 15 inches high, bearing a large white flower, often 2 to $2 \frac{1}{2}$ inches in length and 2 inches wide, turning to lilac color with age. ro cts. each, \$I per doz.

T. erectum. Has broader, rhomboid leaves, with a dark purple flower. ro cts. each, \$I per doz.

T. erectum, var. album. A variety with white or greenish white flowers. $25 \mathrm{cts}$. each, \$1.25 per doz.

T. nivale (Dwarf White Trillium). Small, 2 to 4 inches high. Petals white. Very early. I5 cts. each, \$1.25 per doz.

T. recurvatum. Leaves green with white patches, flowers brown-purple. A most beautiful and easily grown Trillium. $15 \mathrm{cts}$. each, $\$$ r.25 per doz., $\$ 6$ per roo.

T. sessile. 4 to I2 inches high. Flowers dark purple. $20 \mathrm{cts}$. each, $\$$ I. 50 per doz.

T. sessile, var. Californicum. From the Pacific coast. $25 \mathrm{cts}$. each, $\$ 2$ per doz. Large roots.

TROLLIUS laxus (Globe Flower). Flower similar in appearance to a buttercup, but larger. Plant in a moist, shady place. ${ }_{5} \mathrm{cts}$. each, \$I.25 per doz.

UVULARIA grandiflora (Large Bellwort). Generally about ${ }_{5}$ inches high, forking above, bearing numerous membranaceous leaves, and yellowish drooping flowers. Frequently has more than one stalk from the same root. Blooms in early spring. Io cts. each, \$I per doz.

U. perfoliata. Smaller than the last, with leaves more clasping on the stalk. Io cts. each, \$I per doz.

U. sessilifolia. Similar to the above, only the leaves are sessile instead of clasping. All these Uvularias are easily cultivated, and are quite pretty. Io cts. ea., \$I per doz.

VANCOUVERIA hexandra. A fine leafy plant from Oregon, with rather large wheelshaped white flowers. Io cts. each, \$I per doz.

VERNONIA Noveboracensis (Iron Weed). Vigorous growing perennials, with very showy purple flowers in small heads in autumn. Very effective as single specimens, or grown in clumps near water. $20 \mathrm{cts}$. 


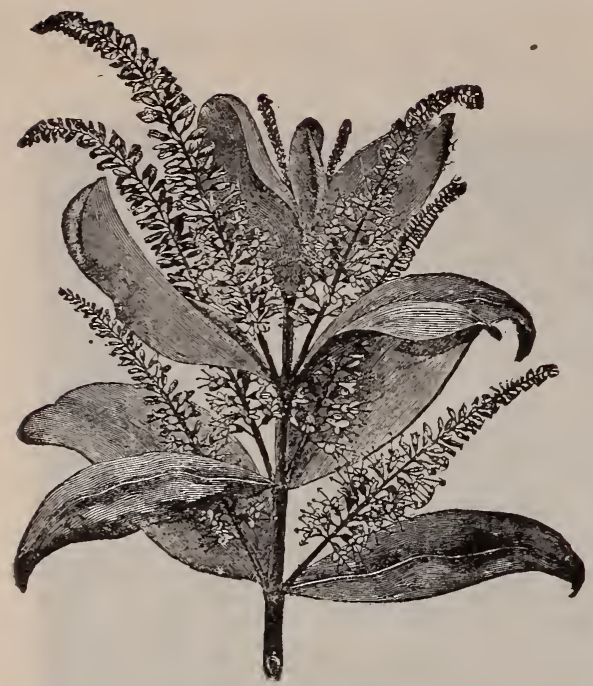

Spray of Veronica

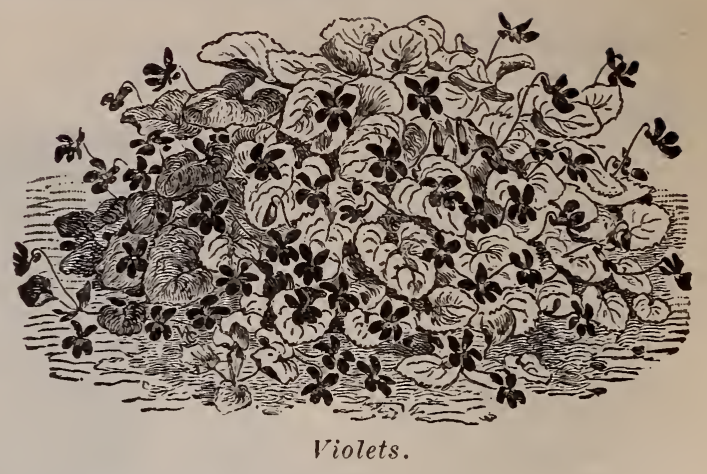

VERONICA gentianoides. Plant 12 to I 8 inches high, with pale blue flowers in a raceme in spring. I 5 cts.

V., var. incana. A pretty little dwarf bedding plant with silvery leaves; flowers dark purple. Choice. I5 cts.

VIOLA. The wild Violets are for the most part among our first spring flowers. They furnish an abundance of bloom, a variety of color, and are so easily grown as to be worthy of a place in every wild garden.

v. Canadensis. Is I to 2 feet high, with heart-shaped leaves, and whitish flowers tinged with purple. Io cts. each, \$I per doz.

v. cucullata (Common Blue Violet). A strong-growing plant from a thic ened or tuberous root; stemless, each leaf and flower-stalk growing on a long stem from the root. Flowers deep or pale violet-blue or purple. Io cts. each, \$I per doz.

v. pubescens. 6 to 12 inches high. Flowers yellow, veined with purple. I 5 cts. each, \$I per doz.

v. rotundifolia. Low, 2 to 3 inches high, with yellow flowers in early spring. ro cts. each, \$I per doz.

v. sagittata. Flowers blue. Plant in dry, open places. Io cts.

v. blanda (Sweet White Violet). Flowers slightly fragrant. Plant in a moist, open place. Io cts. each, \$I per doz.

v. canina, var. sylvestris (Dog Violet). This is a pretty many-flowered Violet, blue in color, branching and forming little clumps. Moist shady places. Io cts. each, $\$$ I per doz.

v. pedata (Bird's-Foot Violet). Leaves all divided. Large, handsome, pale or deep purple or blue flowers in summer. Delights in a dry sandy soil in open sun. Io cts. each, \$I per doz

V. pedata, var. bicolor. A beautiful variety of the above, with two leaves of the flower violet-colored. Does nicely in a sandy loam soil in a partial shade. I5 cts.

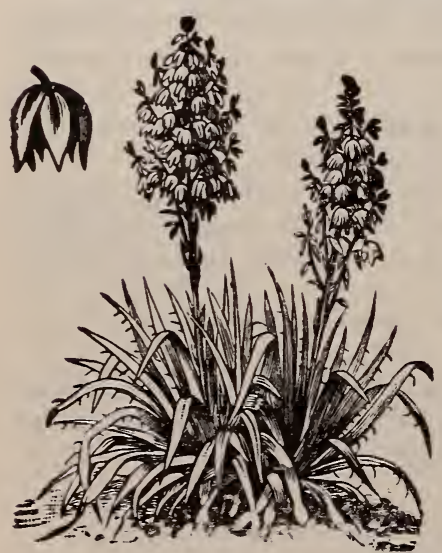

Yucca filamentosa. each, \$I.25 per doz.

VINCA minor (Common Periwinkle). A most beautiful evergreen trailing plant, with blue flowers. Also known by the name of Blue Myrtle. Io cts. each, \$I per doz., \$4 per Ioo.

v. minor alba. A very fine variety with pure white flowers. As easily grown as the Common Periwinkle. I5 cts. each, \$I.25 per doz.

YUCCA filamentosa (Adam's Needle). The dark green leaves, I to 2 feet long, are clustered at the base, about an inch wide in the center, running to a sharp point, the edges splitting off into little hairs I to 4 inches long. The flowers are large, creamy white, borne along the stalk near the top, 3 to 6 feet high. Very ornamental on the lawn. It is an evergreen, and looks well through the winter. Fine plants, $35 \mathrm{cts}$. each, $\$$ I 50 per doz. Too heavy for the mail. Not prepaid. 


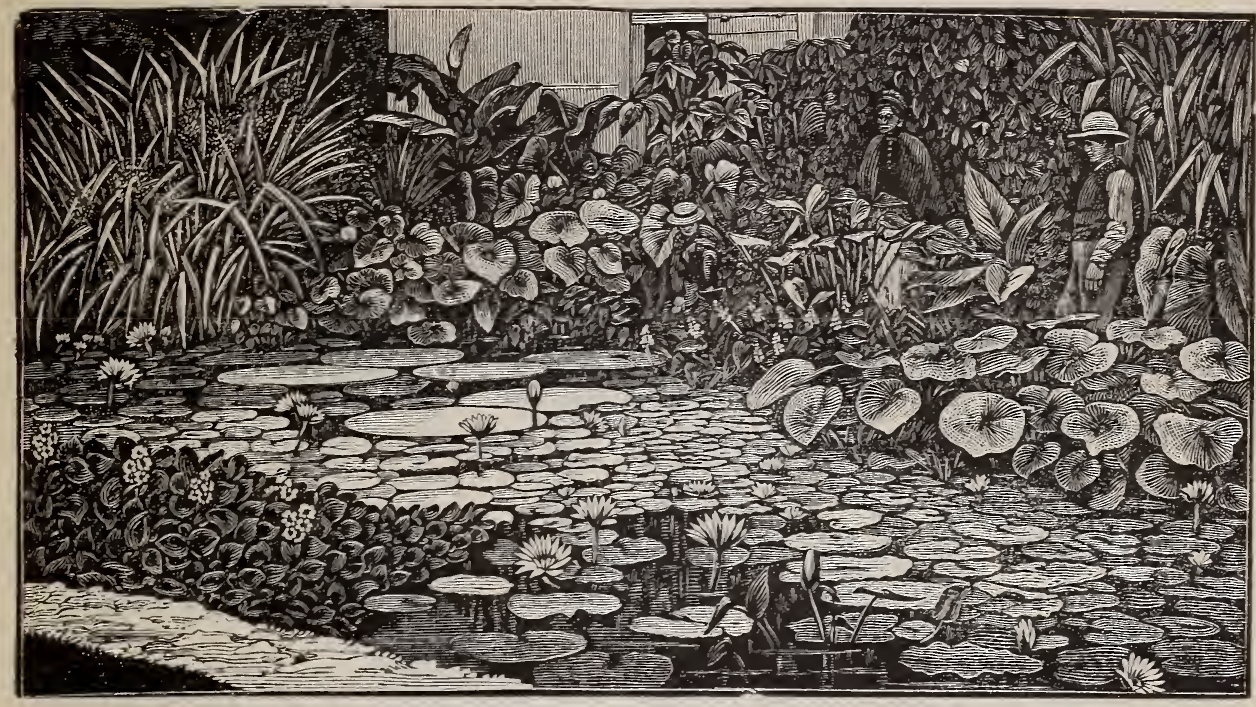

A Water Garden of moderate size.

\section{Bog and Aquatic Plants.}

Bogs and lakes are very essential elements in landscape work. The wet, springy bank and muddy pool below can be made the choicest spots under the magic touch of the progressive gardener of today. These unsightly places are made to produce a great wealth of both flowers and foliage; the muddy pool is transformed into the lake for aquatics, and the springy bank is set to Sarracenias, Dionæas, etc, and made into a botanist's paradise, for here these bog plants are at home.

ACORUS Calamus (Sweet Flag). Grows in low wet places. Leaves light green, I to 3 feet long. The rootstock has an aromatic flavor, well known to people of New England. Desirable for shallow lakes or wet places. Io cts.

A. Calamus variegatus (Variegated Sweet Flag). Leaves beautifully striped with white. Easily grown in any garden soil. $20 \mathrm{cts}$.

ALISMA plantago (Water Plantain). Flowers small, white or rose. Plant in shallow water. Io cts.

BRASENIA peltata (Water Shield). An aquatic growing in I to 6 feet of water. Leaves entire, floating, $x$ to 3 inches broad, greenish or purplish. Flowers small, dull purple, appearing on the water's surface. ro cts. each, \$I per doz.

CALLA palustris (Water Arum, or American Calla). A bog plant, resembling the cultivated Calla in both leaf and flower, only smaller. 6 inches high. Plant near water or mulch with sphagnum moss and keep wet. ro cts. each, \$I per doz.

CALTHA palustris (Marsh Marigold). 6 to I 5 inches high. Flowers bright yellow. A very showy plant. Fine for forcing in pots. Io $\mathrm{cts}$. each, \$I per doz

DIONFEA muscipula (Venus' Fly Trap). A most wonderful plant. The flowers are small, white and quite pretty, but the wonder is centered in the hairy-edged, roundish leaves, which are so sensitive that they quickly close if touched on the inside. Insects are quite often caught and closely held until they die, when the leaftrap again opens and is ready for more game It is easily grown in wet or very damp sand, either in pots or in the open ground, in damp moss or bog. I 5 cts. each, \$1.25 per doz

DROSERA filiformis (Thread-Leaved Sundew). A little bog plant with long, threadlike leaves, covered with short red colored hairs. Flowers rose-purple, along the upper part of the stem. 4 to 8 inches high. Wet, sandy soils. roc each, \$1 per doz.

D. rotundifolia (Round-Leaved Sundew). Found in wet sandy places near water and in sphagnum moss and in a bog. Leaves roundish, covered with red hairs. Flowers white. ro cts. each, \$I per doz.

D. Iongifolia. Similar to the above, only the leaves are narrower. Bogs. ro cts. each, \$1 per doz. 
HELONIAS bullata (Stud Flower). A rare perennial, found in wet places southward, with a few large smooth leaves at the base. Flower stalks I to 2 feet, with a raceme of beautiful pink or purple flowers. Plant in a wet place or bog. $25 \mathrm{cts}$.

IRIS pseudacorus (Yellow Iris). Quite large, bright yellow flowers on stems 2 feet high. $20 \mathrm{cts}$.

JUNCUS effusus (Bog Rush). Stem round, dark green, 2 to 4 feet high, bearing near the top a cluster of small, inconspicuous flowers. Io cts.

LIMNANTHEMUM lacunosum (Floating Heart). A pretty little aquatic, with small blotched leaves and pure white flowers. Io cts. each, \$I per doz.

MENYANTHES trifoliata (Buck-Bean). A pretty little bog plant found growing in moss. Has large, pure white flowers, covered on the upper surface with frost-like beards. Fine for the bog garden. Io cts. each, \$I per doz.

NASTURTIUM officinale (Hardy English Water Cress). A well-known hardy perennial aquatic, easily grown in any stream. Flowers white. $8 \mathrm{cts}$. each, $75 \mathrm{cts}$. per doz.

NESEA verticillata. A pretty little water shrub, found along the margin of lakes in shallow water or wet ground, with clusters of snall rose-purple flowers. Forms large clumps. $25 \mathrm{cts}$. each, $\$$ I.50 per doz.

NUPHAR advena (Common Yellow Lily). Has large leaves and single yellow flowers. 25 cts. each, $\$ 2$ per doz.

NYMPHAEA (Water Lily)-

N. odorata (Sweet-Scented Water Lily). This plant is too generally known to need description. Its large fragrant white flowers are well worth the trouble required in growing them. Where no pond or slow-flowing stream is near at hand, the plant may be grown in a large tub partly filled with rich mud or clay, the roots planted in this and the tub filled with water. $25 \mathrm{cts}$. each, \$1.50 per doz.

PELTANDRA Virginica (Water Arum). Leaves on long petioles, something like a calla in outline, with greenish flowers, growing a foot or more out of the water. $15 \mathrm{cts}$. each, \$I per doz.

PONTEDERIA cordata (Pickerel Weed). Flowers blue. $20 \mathrm{cts}$. each; by express, \$I 50 per doz.

SARRACENIA purpurea (Pitcher Plant). This plant usually sends up a single flowerstalk 6 to 18 inches high, bearing a single deep purple flower an inch or more broad. Leaves pitcher-shaped, curved, ascending, 2 to 6 inches in length. The Sarracenias are all fine bog plants. $15 \mathrm{cts}$. each, \$I per doz.

S. flava (Trumpet Leaf). Flowers and leaves yellow, the former 4 to 5 inches wide, leaves 2 feet long. I5 cts. each, $\$ \mathbf{I} .50$ per doz.

S. Drummondii. Leaves 2 feet long, beautifully variegated; flowers 3 inches wide. $20 \mathrm{cts}$. each, $\$ 2$ per doz.

S. Psittacina (Parrot-Beaked Pitcher Plant). Quite small and rare. $20 \mathrm{cts}$. each, $\$ 2$ per doz.

S. rubra (Red-Flowered Trumpet Leaf). Pitchers red-veined; flowers reddish purple. I5 cts. each, \$I.50 per doz.

S. variolaris. A smaller species from Georgia, with taller and more slender leaves. I $5 \mathrm{cts}$. each, $\$$ I. 50 per doz.

SCIRPUS atrovirens (Marsh Sedge). I to 3 feet high. Fine for moist or wet places. I5 cts. each, \$I per doz.

SYMPLOCARPUS fœitidus. This is one of the earliest of the spring flowers. The covering for the yellow flowers is dull purple, showing above ground before the frost is gone. The large green leaves appear later. $20 \mathrm{cts}$. each, \$I 50 per doz.

TYPHA latifolia (Cat-tail). A plant found in wet places, growing 2 to 4 feet high. Leaves long, grass-like. Flowers grow in a spike. I5 $\mathrm{cts}$. each, $\$ 1.50$ per doz.

VERATRUM viride (White Hellebore). Broad-ribbed, dark green foliage and large heads of greenish white flowers. A good plant for the bog. 4 feet. $25 \mathrm{cts}$.

\section{Shrubs Desirable for a Wet Place.}

Andromeda polifolia, I ft.

Azalea viscosa, 4-Io $\mathrm{ft}$.

Cassandra calyculata, I ft.

Cephalanthus occidentalis, $4 \mathrm{ft}$.

Gaylussacia resinosa, $2 \mathrm{ft}$.

Ilex verticillata, $5 \mathrm{ft}$.

Kalmia angustifolia, I ft.
Kalmia glauca, $2 \mathrm{ft}$.

Ledum latifolium, I $\mathrm{ft}$.

Nemopanthes Canadensis, $4 \mathrm{ft}$.

Pyrus arbutifolius, $5 \mathrm{ft}$.

Rhodora Canadensis, $2 \mathrm{ft}$.

Vaccinium stramineum, $3 \mathrm{ft}$.

Vaccinium corymbosum, 5-ro ft. 


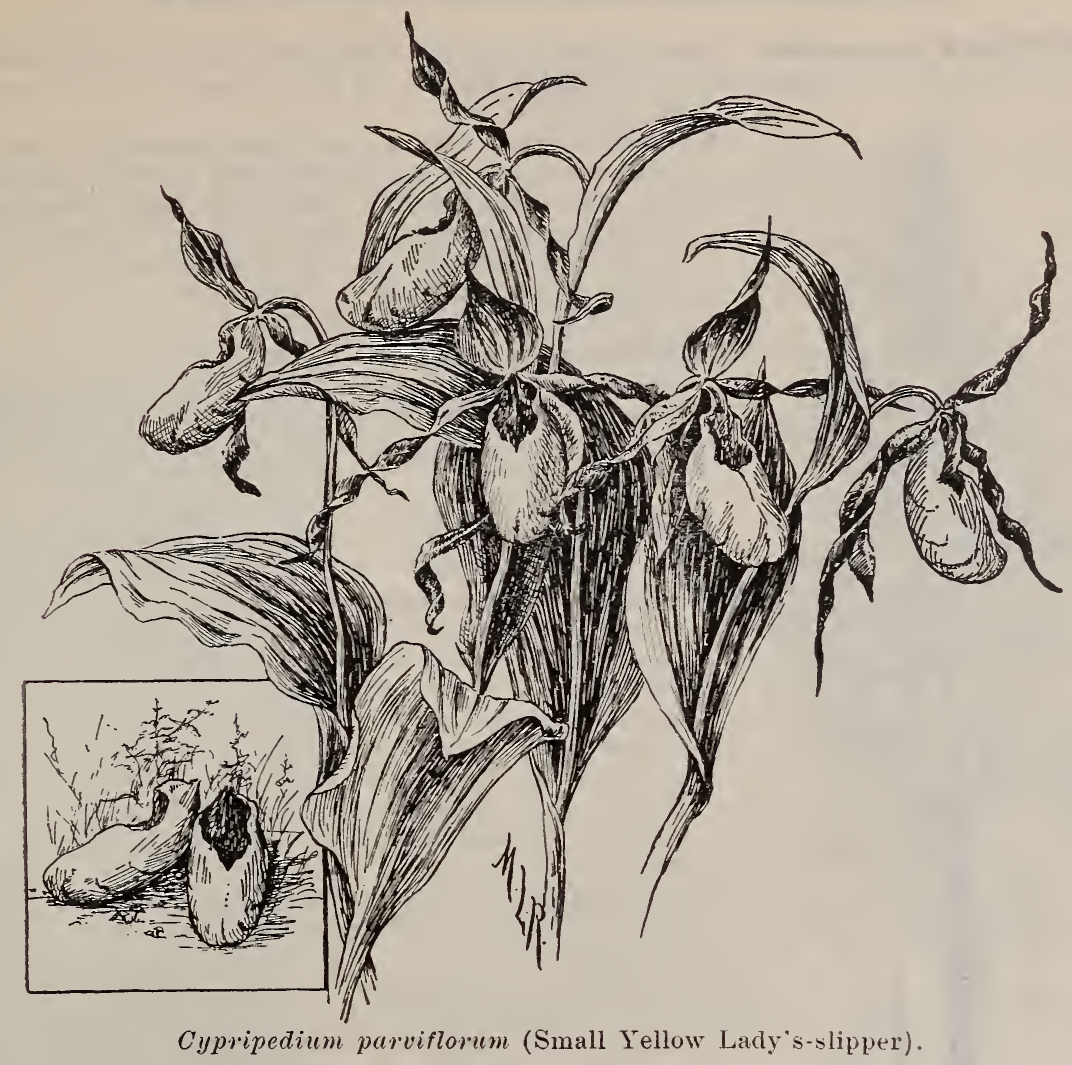

\section{ORCHIDS.}

Among the following will be found a few of our most hardy Orchids, such as may be easily grown. These all like shade at least half or two-thirds of the day, and by planting in a mixture of peat or leaf-mold, in loamy soil or a clay loam, they are easily grown. The mixture of peat or leaf-mold tends to keep them moist. After they are planted, an inch of pure leaf-mold placed over them as a mulch will be very beneficial.

APLECTRUM hyemale (Puttyroot). This plant sends up from a bulbous root late in summer a pointed green leaf, 2 to 6 inches long, which lasts through the winter, and in spring a stalk about a foot high, bearing a raceme of rather large greenish brown flowers. I5 cts. each, \$I per doz.

CALOPOGON pulchellus. Although this plant is more generally found in swamps and peat bogs, it also frequently grows in moist, sandy soil. It is a small bulb about the size of a large bean, which sends up in spring a long, grass-like leaf and a stalk about a foot high, bearing in June and July 2 to 6 showy pink-purple flowers about an inch broad. Io cts. each, \$I per doz.

CYPRIPEDIUM acaule (Lady's-slipper, Moccasin Flower). This is often called the Red Lady's-slipper, but the flower is rose-purple in color. The plant sends up two broadish green leaves from the base, and from between them comes a stalk about a foot high bearing a single large, showy flower. Plant in a dry shady place ; it does nicely under pine trees. I5 $\mathrm{cts}$. each, $\$$ r.25 per doz.

C. Parietinum (Ram's Head Lady's-slipper). Stem leafy, 6 to 12 inches high, bearing a small, dainty, red, brown and white flower. Plant in moist shades. A most beautiful little gem. Rare. 20 cts. each, \$I.50 per doz.

C. parviflorum (Small Yellow Lady's-slipper). A fine yellow Lady's-slipper, fragrant. Shady, well-drained soils. $20 \mathrm{cts}$. 
CYPRIPEDIUM pubescens. Much resembles $C$. farviflorum, but has larger leaves and flowers. Very easily grown in moist shades. A fine bloomer. I5 cts. each,

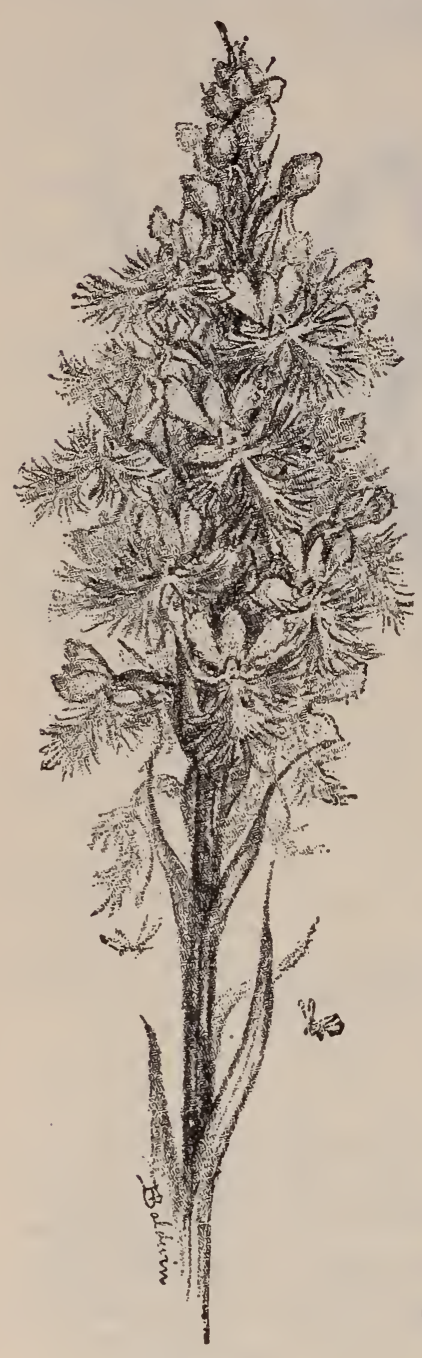

Habenarir.

$\$ 1.25$ per doz

C. spectabile. This is the largest species we have of this genus, and is by far the most beautiful of them all. The plant is about 2 feet high, leafy throughout, bearing one to several large pink, purple and white flowers, $I \frac{1}{2}$ inches long. Its natural home is in rich leaf mold, and you will find it delights in a very moist soil. Fine for the bog. 25 and $50 \mathrm{cts}$.

GOODYERA pubescens (Rattlesnake Plantain). 8 to I 5 inches high, leaves clustered at the bottom, white, reticulated. Stem leafless, about a foot kigh, bearing a short spike of white flowers Plant in a shady place, with leaf-mold. It does nicely in the rock garden. Io cts. each, \$I per doz.

G. Menziesii. A species from the Pacific coast, with large, mottled leaves. $20 \mathrm{cts}$.

HABENARIA blepharioglottis (White Fringed Orchis). A rare and beautiful species found growing in sphagnum moss. I to 2 feet high, bearing at the top a spike of pure white fringed flowers. Rare. At home in the bog. $25 \mathrm{cts}$.

H. ciliaris (Yellow Fringed Orchis). Growth similar to the last, but the flowers are yellow, and very fine. This seems to take readily to cultivation, and thrives nicely in moist garden soil or bog. 20 zts. each, $\$ 1.25$ per doz.

H. psycodes. The flowers are smaller, more crowded than in the last, and deeper purple. I5 cts. each, $\$$ I.50 per doz.

H. Hookeri ('Two-leaved Orchis). The plant has two large leaves growing flat on the ground, with a few small greenish flowers growing along the upper part of the stalk. Found in well-drained leaf-mold under evergreens. I5 cts. each. $\$ 1.50$ per doz.

LIPARIS liliifolia (Twayblade). About 4 inches high, bearing a short raceme of purplish flowers. Plant in well-drained soil; a shady bank is preferable. I5 cts. each, \$I per doz.

L. Losellii (Green Twayblade). With greenish flowers. This plant delights in a wet situation just at the edge of water. I $5 \mathrm{cts}$. each, $\$$ r.25 per doz.

ORCHIS spectabilis (Showy Orchis). Leaves oblong, shiny, 3 to 5 inches long, near the ground. Stem 4 to 7 inches high, bearing a few pink, purple and white flowers. Io cts. each, $\$ \mathbf{l}$ per doz.

POGONIA ophioglossoides. A little fibrous-rooted plant, found growing in sphagnum moss and wet places in leaf-mold. Flowers rose-colored or white. Stalk 4 to ro inches high. Io cts. each, \$r per doz.

SPIRANTHES cernua (Ladies' Tresses). Grows 6 to 20 inches high. Leafy below, bearing at the summit a dense spike of white flowers. Io cts. each, $\$$ r Io per doz.

\section{Tender Plants and Bulbs.}

AMARYLLIS formosissima (Jacobean Lily). A fine plant, with large scarlet flowers. Plant in the open border. The bulbs should be lifted in autumn and kept in a dry place away from frost. I $5 \mathrm{cts}$.

MILLA biflora. Flowers in pairs, pure waxen white, nearly $2 \frac{1}{2}$ inches in diameter; petals thick and leathery, of great substance, and will keep for days when cut and placed in water Bulbs should be taken up and stored away from frost during the winter. $5 \mathrm{cts}$. each, $50 \mathrm{cts}$. per doz.

HYACINTHUS candicans. 3 to 4 feet high, with a long spike or raceme of pearl-white bell-shaped flowers $\mathrm{r} 1 / 2$ to 2 inches long, which are pendent from all around the spike. Io cts. each, \$I per doz. 


\section{Roses.}

In the following list of Roses, only those are mentioned that are particularly desirable on account of their hardiness, easy culture and beautiful flowers. I offer large,

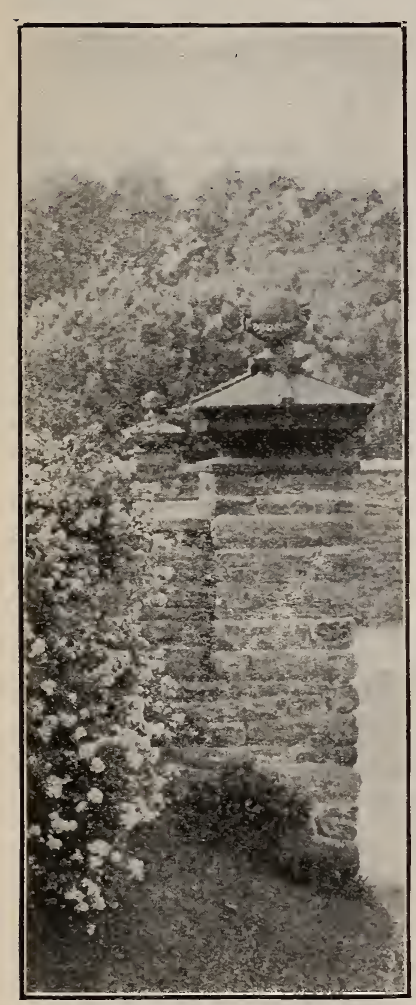

Kosa multiflora.

flowering plants (too large for the mail).

Anne de Diesbach. Flowers large, crimson, fragrant. $35 \mathrm{cts}$.

Baroness Rothschild. Flowers large, light pink, deepening to rose, borne on long stems, and surrounded by fine clusters of dark green leaves. $40 \mathrm{cts}$.

Crested Moss. Deep pink buds, with mossy fringe and crested. A beauty. Fine plants. $50 \mathrm{cts}$.

Fisher Holmes. Deep glowing crimson; large, full, and of fine form. Very fragrant $40 \mathrm{cts}$

General Jacqueminot. This is probably the best known of all Hybrid Perpetuals, and is without a rival in fragrance and richness of color. Crimson $40 \mathrm{cts}$.

Gloire Lyonnaise. A beautiful Rose, with leather-like foliage. Flowers creamy white, shading to lemon at the center. Very double. $40 \mathrm{cts}$.

La France. A very popular Rose, large and beautiful, both in bud and expanded flower. Silvery rose in color, and deliciously fragrant. A great bloomer. $40 \mathrm{cts}$.

La Reine. A beautiful clear bright Rose, large and full. Very hardy. A standard sort. 40 cts.

Louis Van Houtte. Rich crimson, heavily shaded with maroon. Medium size, double and well formed. High perfume. $40 \mathrm{cts}$.

Madame Georges Bruant. This new Everblooming Rose inherits the beautiful foliage and hardiness of the liosa rugosa. Flowers double. in clusters, pure white, very fragrant; buds long and pointed. Blooms at intervals through the season; forms a stout, handsome bush Hardy everywhere. $40 \mathrm{cts}$.

Madame Plantier. This grand variety stands at the head for general usefulness on account of its perfect hardiness and fine bushy form. It is largely planted in cemeteries and exposed positions The flowers are pure white, and borne in great abundance $25 \mathrm{cts}$. each, $\$ 2$ per doz.

Mrs. John Laing. Soft pink, large and full. Very fragrant. A great bloomer and of first quality. $40 \mathrm{cts}$.

Multiflora. A very vigorous sort, making a heavy bush with beautiful pendulous branches which are hidden in the masses of creamy white flowers. Of the very first merit, and worthy of general use as a climber or shrub. $25 \mathrm{cts}$. each, $\$ 2$ per doz.

Paul Neyron. This is a hardy Hybrid Perpetual, with very large deep rose flowers. A strong grower, with very few thorns. Buds especially desirable. $40 \mathrm{cts}$.

Rubiginosa (English Sweetbrier). A very hardy Rose, 4 to 6 feet high, with shining leaves which have a refreshing fragrance, and many small, pink, single, very fragrant flowers. Fruit orange-crimson and quite showy. Fine for hedges. Field grown, 20 cts. each, \$I per doz.

ROSA rugosa. These Japan Roses are very hardy, rapid growers, attaining a height of 5 or 6 feet, rendering them available for impenetrable, ornamental hedges, for which purpose they are unexcelled. The foliage is rather thick in texture, and of the most glossy, luxuriant green. The flowers are large, single, and most perfect in form, followed by the large, bright red or golden apples, which are very showy.

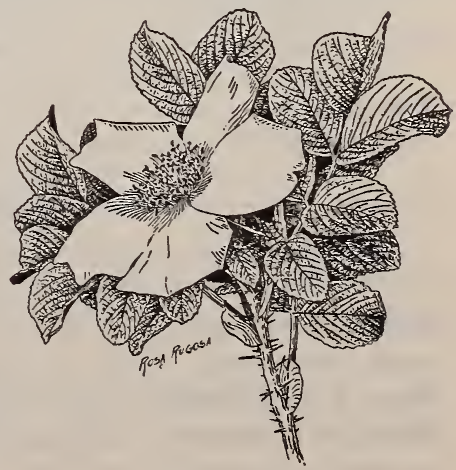

Rosa rugosa. 
ROSA rugosa rubra. Flowers very large, pink in color; the fruit is brilliant crimson. 25 cts.

R. rugosa alba. Lovely pearly white flowers and bright golden fruit. $30 \mathrm{cts}$.

WICHURAIANA (New Japan Creeping Rose). A low trailing species, its stems creeping

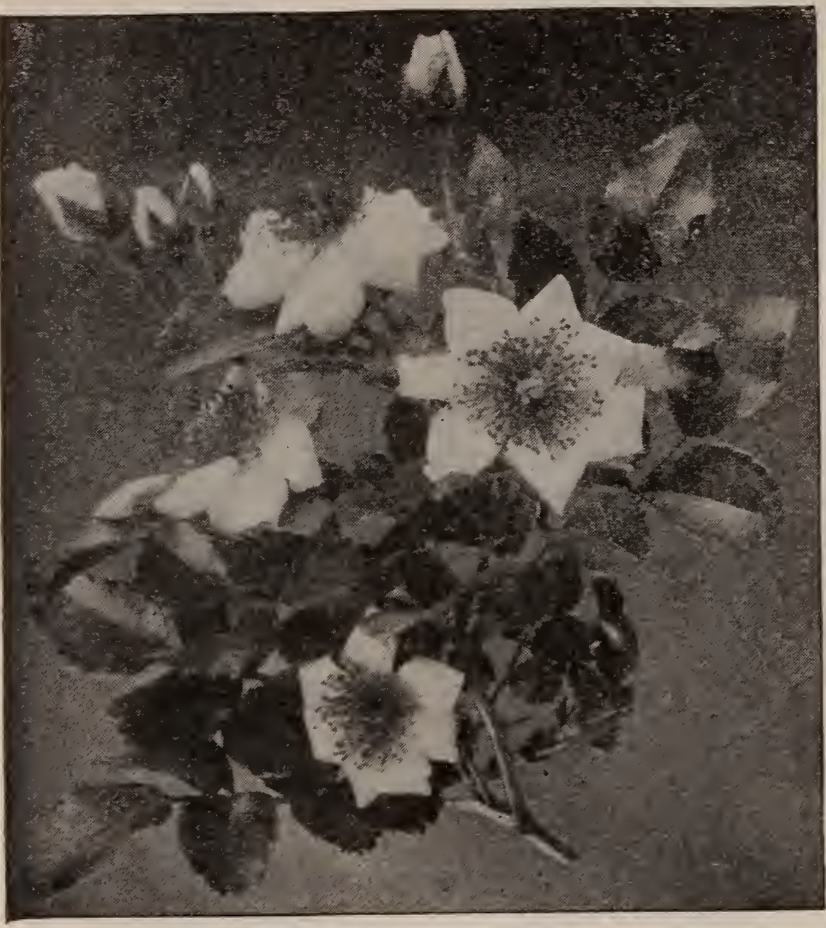

Rosa Wichuraiana. on the earth as closely as an ivy, and forming a dense mat of very dark green lustrous foliage. It is a rapid grower. The flowers are rather small, pure white, with golden yellow stamens. It is perfectly hardy, and very desirable for creeping over walls or covering unsightly places. The four varieties below are its new hybrids. 25 cts. each, $\$ 2.50$ per doz.

South Orange Perfection. Flowers double, white, in masses, soft pink at the tips. $35 \mathrm{cts}$.

Manda's Triumph. Fine glossy foliage ; large clusters of double, white flowers; sweet scented. $35 \mathrm{c}$.

Universal Favorite. Foliage shining; flowers double, bright rose, deliciously fragrant. $35 \mathrm{cts}$.

Pink Roamer. A vigorous grower, with bright foliage; the flowers are single pink, with white centers; very fragrant. $35 \mathrm{cts}$.

\section{CLIMBING ROSES.}

Baltimore Belle. White, very double, flowers in large clusters. The buds are slightly tinged with pink. $40 \mathrm{cts}$.

Crimson Rambler (The Hardy Japan Climbing Rose). This Rose was introduced in I893, and has proved a decided novelty. It is a vigorous grower, making in some cases shoots $\mathrm{I}_{5}$ feet long in a season. The flowers are small, but grow in large glowing crimson bunches, measuring from 6 to 9 inches from base to tip; 300 blooms have been counted on one shoot. The flowers remain a long time in fine condition. Seems to be well adapted to the entire country, and should be in every collection. 5oc.

Yellow Rambler (Aglaia). This, like Crimson Rambler, is a very vigorous climbing Rose, bearing its yellow flowers in clusters, and proving very hardy. Large plants. $50 \mathrm{cts}$.

Pink Rambler. A hybrid between Rosa multiflora and General Jacqueminot. Flowers double, deep pink. Fragrant. $40 \mathrm{cts}$.

Setigera (Wild Prairie Rose). This is a hardy climbing Rose, with good-sized single pink flowers. $35 \mathrm{cts}$.

\section{SWEETBRIER HYRRIDS.}

These Hybrid English Sweetbriers are quite hardy, retaining the delightful fragrance of the Rubiginosa or Eglantine, and showing some of the finest tints imaginable. $40 \mathrm{cts}$.

Mina. Soft copper tint, with a yellow throat.

Lord Penzance. Fawn color, shading to bright yellow.

Rose Brandwardine. Pure white, tinted with rose. Flowers large.

Anne of Gierstein. Brilliant crimson. Fine.

NATIVE ROSES. See Shrubs. 


\section{Hardy Vines and Creepers.}

AMPELOPSIS quinquefolia (Virginia Creeper). A well-known climber, very hardy, and greatly used for climbing on stone. Forms a beautiful green covering, and in autumn is beautifully colored. It can also be used to cover dry places on the soil, forming there great mats. $25 \mathrm{cts}$. each, $\$ \mathrm{I} .50$ per doz.

APIOS tuberosa (Wild Bean). A pretty tuberous-rooted climber, with clusters of rich purple flowers. Io cts. each, \$I per doz.

BIGNONIA radicans (Trumpet Creeper). Climbs high trees by rootlets. A beautiful vine with showy tubular orange and scarlet flowers, 2 inches long. $25 \mathrm{cts}$.

CELASTRUS scandens (Staff Tree, Bittersweet). A twining shrub, its principal attraction being in its twining habit and orangecolored fruit, which is very ornamental in autumn. I5 cts. each, \$I per doz.

Clematis coccinea (Scarlet Clematis). A pretty southern species, with large scarlet flowers. Hardy. $25 \mathrm{cts}$ each, \$I 50 per doz.

C. crispa. A beautiful bluish purple flowered species from North Carolina. 25 cts. each, $\$$ I. 50 per doz.

C. Jackmanni. Flowers very large, 4 to 6 inches in diameter, violet-purple and distinctly veined. A continual bloomer through the season. The standard sort. $50 \mathrm{cts}$.

C. paniculata. July to September. "One of the finest of hardy climbers, with handsome foliage. Of very vigorous and rapid growth, producing in late summer dense sheets of medium-sized, pure white flowers of the most pleasing fragrance. This is a new Japanese plant, perfectly hardy, and finely adapted to use for any covering purpose. "J. W. Manning. $35 \mathrm{cts}$.

C. Virginiana (Virgin's Bower). Although quite common in many localities, it is one of the prettiest, both on account of its clusters of numerous white flowers and its featherytailed fruit in autumn. Banks of brooks and streams, climbing over shrubs, Lovely in its native habitat, and also where grown for its beauty. $20 \mathrm{cts}$. each, \$I per dozen.

LONICERA brachypoda. A very hardy, thrifty vine, with large green leaves that stay on through the winter. Especially desirable for planting near the sea. Flowers white and yellow. One of the very best climbers. $25 \mathrm{cts}$. each, \$I.50 per doz.

L. brachypoda aurea. A variety of the above, with leaves beautifully striped with yellow. $25 \mathrm{cts}$. each, $\$ \mathrm{I} .50$ per doz.

MENISPERMUM Canadense (Canadian Moonseed). A pretty vine, with peltate leaves and small white flowers. Fruit black, looking like frost grapes. $25 \mathrm{cts}$. each, $\$ \mathrm{I} .25$ per doz.

RUBUS hispidus (Running Swamp Blackberry). I5 cts. each, \$I per doz:

VACCINIUM Oxycoccus (Small Cranberry). Fine for the bog. I5 cts. each, \$I per doz.

V. macrocarpon (Large or American Cranberry). Try it in the bog. $8 \mathrm{cts}$. each, $50 \mathrm{cts}$ per doz. 


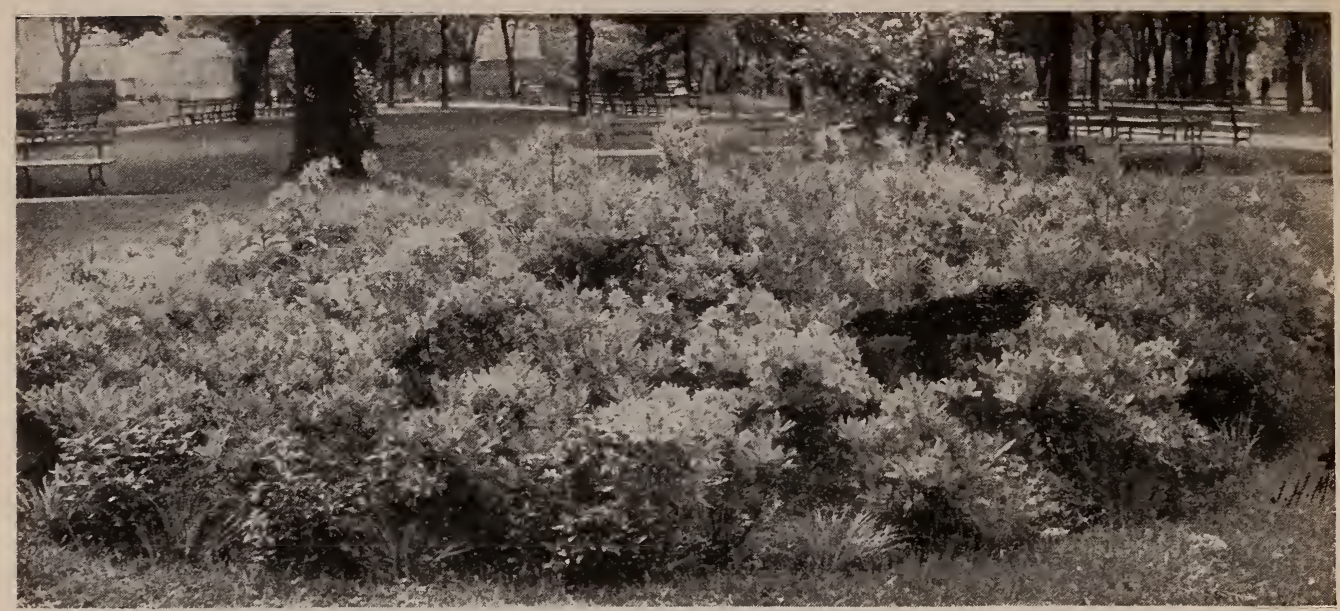

A Bed of Azaleas.

\section{Shrubs and Trees.}

Shrubs and trees are too large for the mail and should go by freight or express.

ABIES Canadensis (Hemlock). A beautiful hardy evergreen, with graceful drooping branches. Desirable for open, exposed places, growing often 50 feet high. It is also one of the very best for hedge planting and stands almost any amount of trimming. $25 \mathrm{cts}$. and $50 \mathrm{cts}$.

A. Engelmanni. From Colorado. An evergreen of much beauty. 2 feet. $50 \mathrm{cts}$.

A. nigra (Black Spruce). A dark evergreen tree, with short stiff leaves. Can be grown in very wet ground. $25 \mathrm{cts}$.

ACER Pennsylvanicum (Striped Maple). Beautifully striped bark and deep green, broad foliage. I5 cts. each, \$1.50 per doz.

A. spicatum (Mountain, or White-Barked Maple). A fine, thrifty plant, with deep crimson twigs, leaves sharp-pointed. Forms large, fine clumps, $25 \mathrm{cts}$.

A. saccharinum (Sugar, or Rock Maple). 5 to 7 feet high. $35 \mathrm{cts}$.

ALTHEA (Shrubby Hibiscus, or Rose of Sharon). A class of shrubs especially desirable on account of their blooming so late in the season when so few other shrubs are in flower. August and September. The flowers are of large size and of many brilliant colors. It forms fine clumps, is very hardy and well adapted to any good soil.

A. purpurea variegata. Purple-flowered, with variegated foliage. $25 \mathrm{cts}$.

A. rubra plena. Double, clear red. $25 \mathrm{cts}$.

A. totus albus. Single, pure white. $25 \mathrm{cts}$.

A. speciosa. Double, pink. 25 cts.

AMELANCHIER Canadensis (Shad Bush). Often 30 feat high. One of the first to flower. Flowers numerous, white, in pretty racemes. $25 \mathrm{cts}$. each, \$I.50 per doz.

AMORPHA fruticosa (False Indigo). Dark purple flowers in a spike. A tall shrub, quite showy. 2 to 3 feet. 25 cts.

ANDROMEDA polifolia. A beautiful little evergreen which takes readily to cultivation, forming a compact mass of foliage 2 or more feet across and 10 or 12 inches high. Flowers bell- or urn-shaped, pale pink or flesh color in May. It also does nicely in the bog. $15 \mathrm{cts}$. each, $\$$ r.25 per doz.

ARALIA pentaphylla. From Japan. Branches spiny; leaves deeply divided, bright glossy green. 6 feet. $25 \mathrm{cts}$.

AZALEA arborescens (Smooth Azalea). Flowers large, pure white and fragrant. I to $I \frac{1}{2}$ feet. $50 \mathrm{cts}$.

A. calendulacea (Flame-Colored Azalea). This shrub is a native of the southern states, growing from 3 to ro feet high, bearing a profusion of beautiful orangecolored flowers, which turn to flame-color with age. Hardy i to $I \frac{1}{2}$ feet. $50 \mathrm{cts}$. each, \$3 per doz. 
AZALEA nudiflora (Purple Azalea). This is one of the finest of our native shrubs, growing from 2 to ro feet high in dry woodlands and swamps, forming clumps. The tubular flowers are very showy, varying from almost white and flesh-color to pink or purple $25 \mathrm{cts}$. each, \$1.50 per doz.

A. Vaseyi (Rhododendron). A species but recently discovered in the mountains of North Carolina. It grows quite tall and seems to respond to cultivation readily, adapting itself to almost any situation, the flowers varying from light pink to deep rose-color, mottled at the base inside. Hardy in New England. The leaves take on beautiful tints in autumn, which give a new charm to this class of plants. I2 to 18 inches. $50 \mathrm{cts}$. each, $\$ 4$ per doz.

A. viscosa (Sweet White Honeysuckle). Grows 4 to Io feet high, with white or slightly rose-tinged flowers, very fragrant. This shrub takes readily to cultivation, forming fine, large clumps. Nice plants with bloom buds, 25 cts. each; large clumps, 50 cts. each; $\$ 1.50$ to $\$ 2.50$ per doz.

BERBERIS purpurea (Purple Barberry). A very choice variety, with deep purple foliage through the season. One of the very best for hedge-work. $25 \mathrm{cts}$. each, $\$ 1.50$ per doz.

B. Thunbergii (Thunberg's Japan Barberry). A low bush, with shining foliage and showy flowers. Fruit deep crimson, persistent through the winter. Fine as single plants or for a low hedge. 3 feet $35 \mathrm{cts}$. each, $\$ 2$ per doz.

B. vulgare (Common, or European Barberry). Handsome upright shrubs forming large clumps. Flowers handsome, yellow, in drooping racemes. One of the very best hedge plants. $25 \mathrm{cts}$. each, \$1.50 per doz.

B. Canadensis. I to $\mathrm{I} 1 / 2$ feet. Rare. $35 \mathrm{cts}$.

BETULA papyracea (Paper or Canoe Birch). A tall tree, with white bark which easily separates into thin layers. $25 \mathrm{cts}$. each, $\$ 1.25$ per doz.

CALYCANTHUS floridus (Sweet Shrub). Flowers purple; bark and foliage aromatic. 25 cts. each, \$1 25 per doz.

CASSAN DRA calyculata (Leather-leaf). A low, branching shrub, with nearly evergreen leaves, bearing in early spring leafy racemes of small white flowers. 15 cts. each, \$1 per doz.

CASTANEA Americana (Chestnut). A large spreading tree, with sweet, edible nuts. A fine native ornamental. Delights in a moist, well-drained soil. $25 \mathrm{cts}$

CEANOTHUS Americanus (New Jersey Tea) A low, branching shrub, $I$ to 2 feet high, bearing in great profusion spreading panicles of white flowers. $25 \mathrm{cts}$. each, $\$ 1.50$ per doz.

CELTIS occidentalis (Hackberry). A medium-sized tree, fantastic in shape, bearing sweet and edible fruit of the size of small cherries. $25 \mathrm{cts}$. each, \$I. 50 per doz

CEPHALANTHUS OCCIdentalis (Button Bush). A fine shrub, bearing round heads of white flowers. Blooms in July. 25c. each, \$1.50 per doz.

\section{CERCIS Canadensis}

(A merican Judas Tree). A small tree, with heart-shaped leaves, bearing its pink flowers in great profusion in early spring. 25 and $50 \mathrm{c}$.

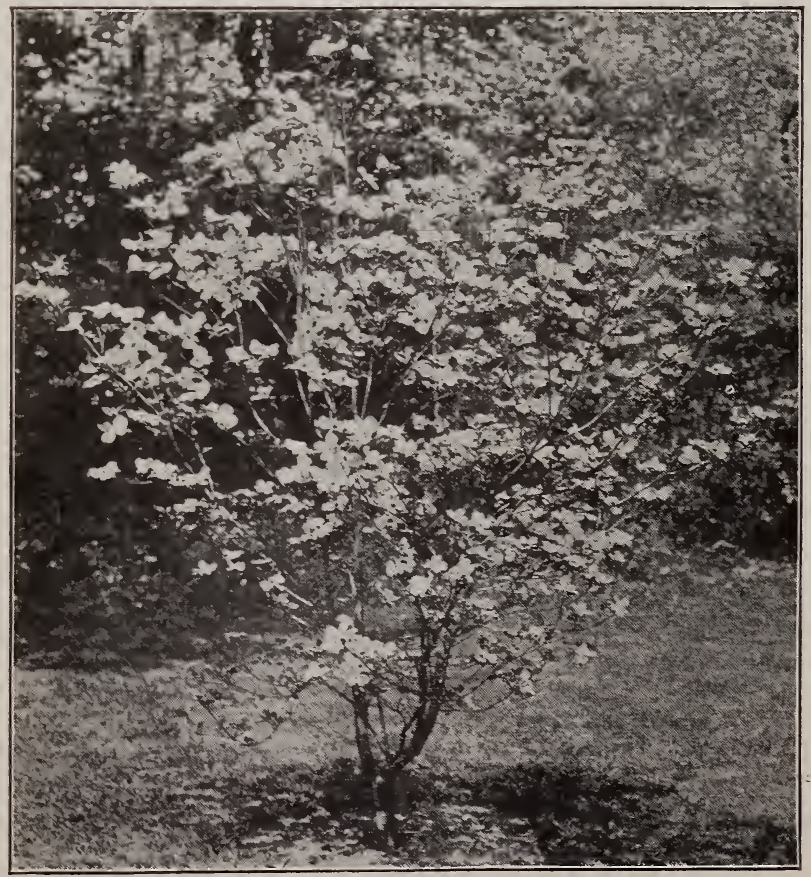

Flowering Doguood (See page 28). 


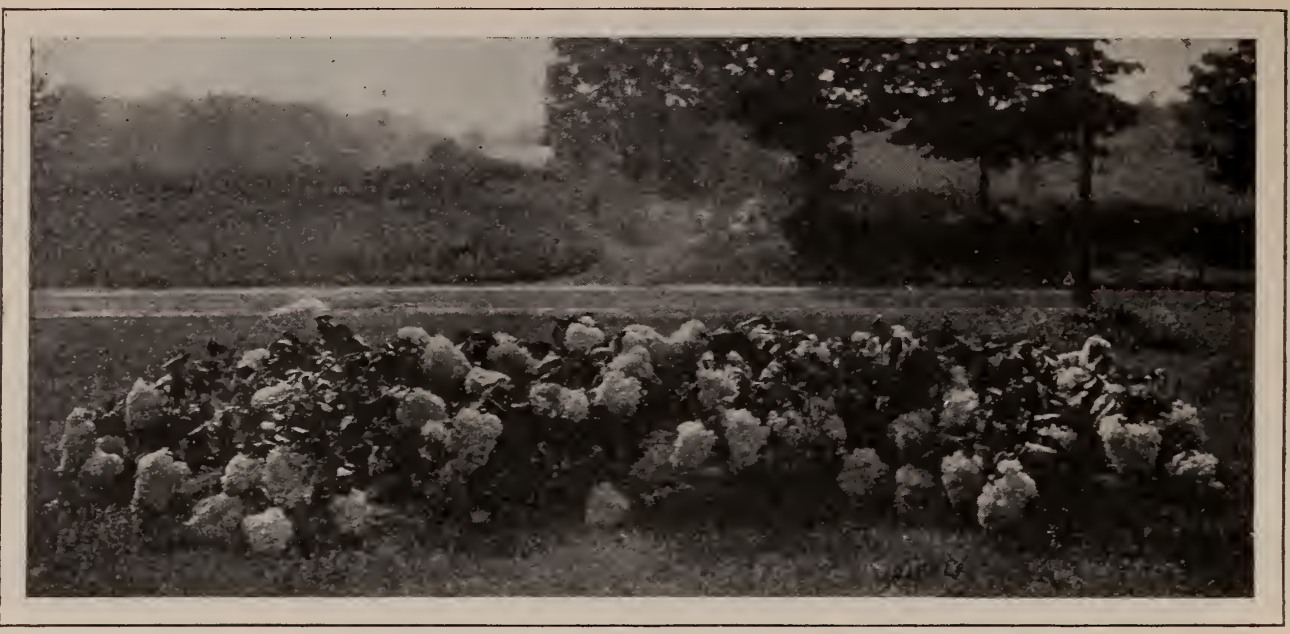

Hydrangea paniculata, rar. grandiflora. (See opposite page.)

CLETHRA alnifolia (Sweet Pepper Bush). Flowers creamy white, very fragrant. Grows 3 to 5 feet high. 25 cts.

COMPTONIA asplenifolia (Sweet Fern). A low shrub, with sweet-scented foliage. I 5 cts. each, \$I per doz.

CORNUS (Dogwood)-

C. alternifolia (Green Osier). A shrub-like tree, 8 to 20 feet high, with wide spreading branches and a flat top. Flowers pale yellow or white; fruit deep blue. $20 \mathrm{cts}$. each, \$1.25 per doz.

C. circinata. 5 to 8 feet high, with large white flowers; fruit light blue. One of the prettiest in cultivation. Leaves larger than in any other species. $25 \mathrm{cts}$. each, $\$$ I. 50 per doz.

C. florida (Flowering Dogwood). A large shrub or tree, often 30 feet high. Flowers white. Very showy in flower and fruit. Fine plants. $25 \mathrm{cts}$. each, $\$ 2$ per doz

C. mas (Cornelian Cherry). Has quantities of yellow flowers in early spring, followed by brilliant crimson edible fruit. I I $1 / 2$ feet. $25 \mathrm{cts}$.

C. paniculata. Grows 4 to I 2 feet high; bark gray. 25 cts. each, \$I.50 per doz.

C. Sanguinea (Red Osier). A fine thrifty shrub, 6 to 8 feet high, with greenish white flowers and deep red bark. $25 \mathrm{cts}$. each, \$1.50 per doz.

C. sericea (Silky Cornel). A shrub 3 to Io feet high, with purplish bark, white flowers and pale blue fruit. One of the latest to flower. $25 \mathrm{cts}$. each, \$I.5O per doz.

C. stolonifera (Red Osier). Handsome in winter on account of its bright reddish purple bark. $25 \mathrm{cts}$. each, $\$$ I.50 per doz.

CORYLUS Americana (Wild Hazel-nut). A shrub 3 to 6 feet high. Flowers in catkins in early spring. $20 \mathrm{cts}$. each, \$I.25 per doz.

DEUTZIA crenata. A shrub 5 feet high, with single white flowers in June and fine leaves. $25 \mathrm{cts}$.

DIRCA palustris (Moosewood, Leatherwood). Shrub 2 to 5 feet high. Flowers light yellow, preceding the leaves. $20 \mathrm{cts}$. each, $\$$ I 50 per doz.

DIERVILLA trifida (Bush Honeysuckle). A little low shrub, with pale yellow flowers and ovate-pointed leaves. $20 \mathrm{cts}$. each, $\$$ I per doz.

ENONYMUS Americanus (Strawberry Bush). A low native shrub, with greenish purple flowers, and rough, warty pods, which are crimson when ripe. $25 \mathrm{cts}$. each, $\$ 150$ per doz.

E. Americanus, var. obovatus. A beautiful variety of the above, forming fine bushy miniature clumps, and flowering when 6 inches high. The large crimson fruit in autumn makes it a very desirable low shrub. $25 \mathrm{cts}$. each, \$I.50 per doz.

E. atropurpureus (Burning Bush). A tall shrub, with dark green leaves and greenish flowers: The crimson fruit on long stems is very showy in autumn. Fine, thrifty, established plants 25 cts. each, \$1.50 per doz.

E. radicans, var variegata (Variegated Creeping Euonymus). An evergreen creeper, with beautiful variegated white, pink and golden striped leaves. Fine for edging. Very prominent in winter. I foot. $25 \mathrm{cts}$. each, $\$$ I.50 per doz. 
FAGUS purpurea (Purple Beech). Leaves of a very deep purple color. One of the very best for a lawn tree. Fine specimens, 4 to 6 feet. \$1.25.

FORSYTHIA suspensa (Weeping Golden Bell). A beautiful shrub with drooping branches. Flowers yellow, quite showy. $25 \mathrm{cts}$.

F. viridissima. Flowers light yellow, in great abundance along the branches. 25c.

GAYLUSSACIA resinosa (Black Huckleberry). The common huckleberry of our woods. Very sweet fruit. Grows about 2 feet high. $25 \mathrm{cts}$. each, $\$ 1.50$ per doz.

HAMAMELIS Virginica (Witch-hazel). A tall shrub, with oval or obovate leaves. It flowers in autumn about the time leaves begin to fall, and matures its fruit the next season. $25 \mathrm{cts}$ each, $\$$ I. 50 per doz.

HYDRANGEA arborescens (Wild Hydrangea). The earliest of this genus to flower. A vigorous shrub 4 feet high, with flat cymes of yellow-white flowers. $25 \mathrm{cts}$. each, \$I 50 per doz.

H. radiata. A thrifty shrub from the southern Alleghany mountains, with white flowers similar to the above. The leaves are large, dark green on the upper surface, and woolly white on the lower side. The beauty is disclosed with every breeze, by turning a leaf here and there, and showing the woolly white against the background of dark green. Hardy, forming good clumps. 25 cts. each, \$1.50 per doz.

H. paniculata (Panicled Hydrangea). A vigorous plant, thickly studded with long terminal panicles of creamy white flowers in autumn. $50 \mathrm{cts}$.

H. paniculata, var. grandiflora. The showiest of autumn-blooming shrubs. Great heads of creamy white flowers turning to shades of red. It blooms late in the season, when most other shrubs are past blooming. $50 \mathrm{cts}$.

ILEX verticillaris (Black Alder or Winter Berry). A native shrub, bearing in autumn beautiful scarlet berries, which stay on until well into the winter. $25 \mathrm{cts}$. each, $\$ 1.25$ per doz.

JUNIPERUS communis (Common or Prostrate Juniper). A prostrate evergreen shrub, appearing as if the center bud had been pinched out and the growth hadconcentrated in the branches. Each one pushes outward and up a foot or more, forming a miniature tree in itself, the whole plant forming a beautiful shrub. 25c.

J. Virginiana (Red Cedar). A beautiful shrub or tree, with small pointed leaves. A slow grower but very hardy, adapting itself to almost any situation, from the top of the rocky cliff to the sandy plain or moist hillside. Color varies from light to dark green and dull slate. $25 \mathrm{cts}$.

KALMIA angustifolia (Sheep Laurel). A low evergreen shrub, I to 2 feet high, with light green leaves and quantities of little saucershaped crimson flowers in May and June. Of easy culture, forming little clumps. $20 \mathrm{cts}$. each, \$r.25 per doz.

k. glauca (Pale Laurel). About a foot high, with little, narrow shining leaves, and large showy white to lilac-purple flowers. $20 \mathrm{cts}$. each. $\$ 1.25$ per doz.

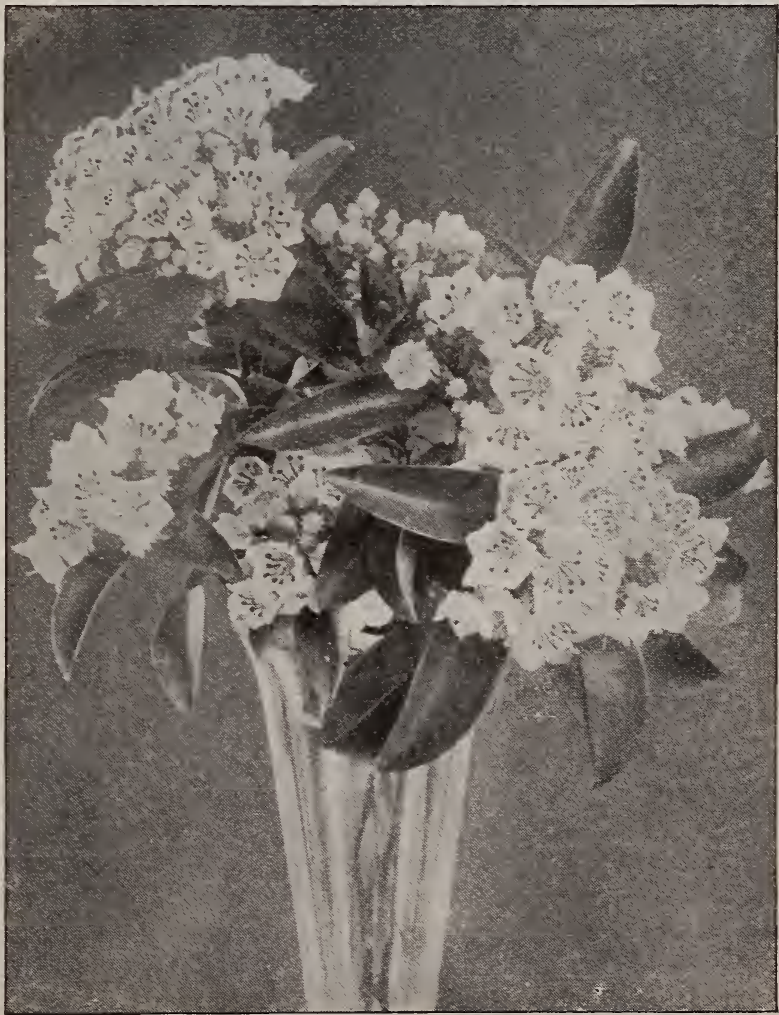

Kalmia latifolia. (See page 30). 
KALMIA latifolia (Calico Bush, Mountain Laurel) An evergreen shrub, growing luxuriantly along our mountain sides, forming large patches; or in single round-topped

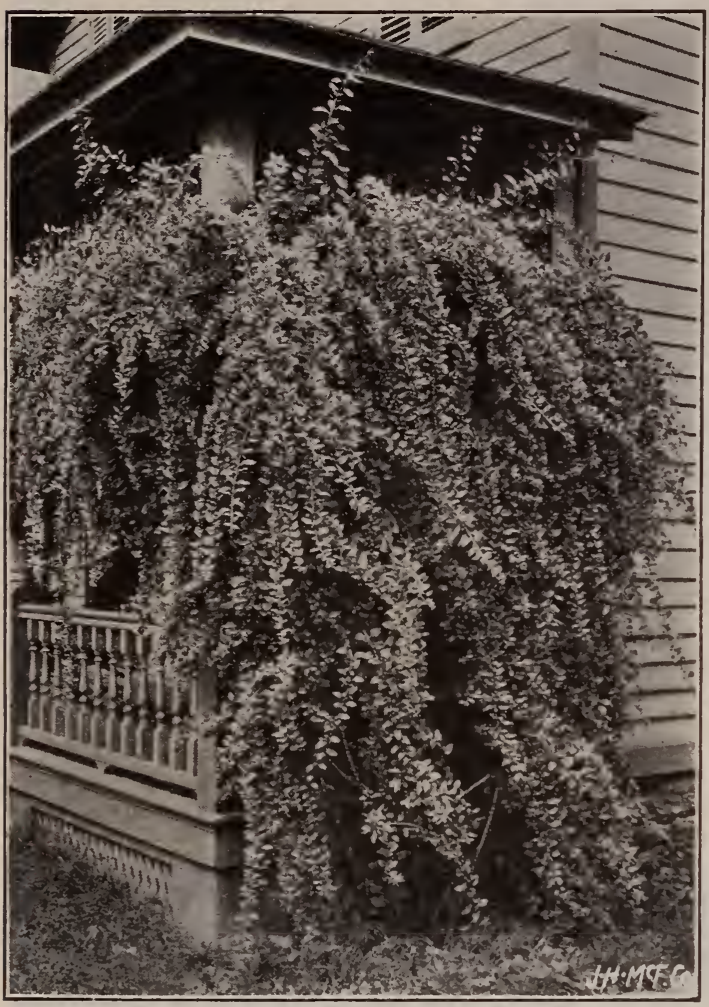

Lycium Chillense (Matrimony Tine). specimens in moist, open fields, the dark shining leaves giving a brightness to the landscape. In May and June the gorgeous coloring of the large rose or white flowers lends an enchantment to the picture that one will not soon forget. It is of easy culture in almost any situation. I have a good stock to select from in size, shape and color: 6 to 9 inches, 20 cts. each, $\$$ I.25 per doz.; 9 to I 2 inches, $30 \mathrm{cts}$. each, $\$ 2$ per doz ; I to $I \frac{1}{2}$ feet, $50 \mathrm{cts}$. each, $\$ 3$ per doz.; I $1 / 2$ to 2 feet, $\$$ I each, $\$ 5$ per doz.; 2 to 3 feet, $\$ 3$ each, $\$ 25$ per doz.

IAURUS Benzoin (Spice Bush). Grows 6 to 15 feet high, with large oblong ovate leaves. $25 \mathrm{c}$. each, \$1.50 per doz.

S. officinale (Sassafras). Grows I 5 to 30 feet high. Flowers greenish yellow, appearing with the leares; bark spicy and aromatic. I 5 cts.

LEDUM latifolium (Labrador Tea). A dwarf evergreen, I to 2 feet high, with handsome heads of white flowers. Leaves with revolute margins, covered underneath with yellow wool. $25 \mathrm{cts}$ each, \$I.50 per doz.

LEUCOTHÖ̈ Catesbæi. A fine evergreen shrub, 2 to 4 feet high, with deep glossy green foliage; flowers white, in showy spikes. Easily handled in a moist, shady place. $25 \mathrm{cts}$. each, $\$ \mathrm{I} .50$ per doz.

LIGUSTRUM ovalifolium (California Privet). A very hardy Privet from California : grows 4 to 6 feet. The finest for hedge plants, also for seashore. I to 2 feet. $25 \mathrm{cts}$.

L. Ibota. A broad form, also good for hedge $25 \mathrm{cts}$ :

L. vulgare (Common Privet). Forms fine clumps. Flowers white, followed by black berries. 25 cts.

LIRIODENDRON Tulipifera (Tulip Tree). A tall native tree, pyramidal in outline, with broad leaves and tulip-like flowers. Light yellow in color. 4 years 25 cts. each, \$I.50 per doz.

LONICERA ciliata (Fly Honeysuckle). Shrub, 3 to 5 feet high. Flowers greenish yellow. $20 \mathrm{cts}$. each, \$I per doz.

L. oblongifolia. Grows 2 to 5 feet high, with yellowish-white flowers, oblong leaves and purple fruit. Does well in cultivation. $25 \mathrm{cts}$,

LYCIUM Chinense (Matrimony Vine). A shrubwith long, recurved drooping branches. Flowers small, greenish purple, followed by orange-red berries Desirable for covering old walls, etc., growing quickly. $25 \mathrm{cts}$. each. \$1.25 per doz.

MAHONIA aquifolia. Low, flowering when 2 feet high; flowers yellow. The leaves are evergreen and of the most beautiful tints imaginable: from dark green to light shades of scarlet and purple. Some are dull, while others are of glossy shades. Quite hardy. Leaves greatly admired for table decoration. $25 \mathrm{cts}$. each, \$2 per doz.

MYRICA cerifera (Bayberry, or Wax Myrtle). Three to 5 feet high, forming good clumps, with rather small, deep green, shining leaves, having a rich fragrance. It takes readily to cultivation even when planted on the seashore. 25c. each, \$I.50 per doz.

M. gale (Sweet Gale). The flowers come out before the leaves. Foliage bright green and fragrant. Does nicely near the water. 4 feet. 25c. each, $\$ \mathrm{r} .50$ per doz. 
NEMOPANTHES Canadensis (Mountain Holly). A medium-sized shrub, with bright red berries in autumn. $25 \mathrm{cts}$. each, $\$ 2$ per doz.

PHILADELPHUS coronarius (Syringa, or Mock Orange). A tall shrub, with large, pure white flowers in June A rapid grower. $25 \mathrm{cts}$.

P. grandiflorus (LargeFlowered Syringa). A rapidgrowing shrub. Io to 12 feet. 25 cts.

PTELEA trifoliata (Hop Tree) A small tree, with curious winged seed - vessels. Fine specimen, nursery grown. 5oc.

PYRUS arbutifolius. A shrub, with small, shining leaves beautifully tinted in autumn $25 \mathrm{cts}$. each, \$1.50 per doz.

QUERCUS alba (White Oak) One of the largest and most admired of our native Oaks Forms a good-shaped tree Plants 2 feet, $25 \mathrm{cts}$.

Q. bicolor (Swamp White Oak) A tall tree in rather low grounds. Plants 2 feet, $25 \mathrm{cts}$

Q. coccinea (Scarlet Oak). A large, round-topped tree, with bright shining leaves, turning to brilliant shades in autumn. Plants 3 feet, 35 cts.

Q. ilicifolia (Black Scrub Oak) A low-growing shrub, 3 to 6 feet, high, desirable for dry sandy soils. Plants 2 feet high, $25 \mathrm{cts}$.

Q. nigra (Black Jack). Low tree not often over $25 \mathrm{ft}$. high, with

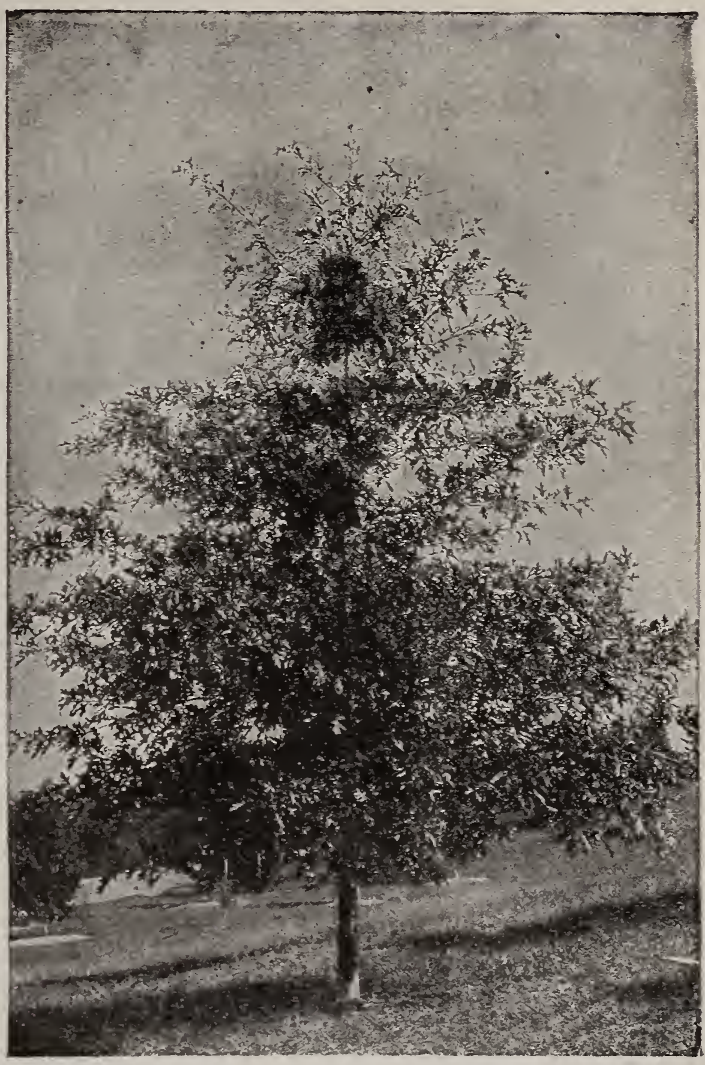

Quercus palustris (Pin Oak). dark green leaves. This, like the Scrub Oak, likes a dry soil. Plants 2 feet, $25 \mathrm{cts}$.

Q. palustris (Pin Oak). This Oak is of exceedingly good form. The branches are somewhat drooping, leaves are very deeply cut, glossy green and of the most gorgeous tints in autumn. Plants 2 feet high, $25 \mathrm{cts}$.

Q. rubra (Red Oak). This is one of the largest of the Oaks, forming symmetrical tops. The leaves are showy in autumn. Plants $3 \mathrm{feet}, 35 \mathrm{cts}$.

RETINOSPORA (Japan Cypress). Evergreen tree desirable for lawns well protected from winds. We get fine sprays and colors in this choice Cypress.

R. ericoides (Health-Leaved Japan Cypress). A beautiful dwarf evergreen shrub, forming a round head. Leaves small, bluish green. I offer fine thrifty plants about $I \frac{1}{2}$ feet high at $35 \mathrm{cts}$.

R. plumosa. A most beautiful Japan Cypress, with short dark green leaves thickly studding the branches, forming very fine sprays. Nicely formed, nursery grown plants, 4. years old, about I I 12 feet hinh. $35 \mathrm{cts}$.

R. plumosa aurea. A variety of the above, with the leaves golden tinted. Very thrifty plants, about $I \frac{1}{2}$ feet high. $35 \mathrm{cts}$.

RHAMNUS alnifolius. About $I^{1} / 2$ feet high, clothed with yellow-green leaves. Takes readily to cultivation. It possesses nuuch merit as an ornamental plant on account of its compact habit and handsome foliage. $20 \mathrm{cts}$. each, \$I per doz.

RHODODENDRON punctatum. A hardy species, flowering when but 3 or 4 feet high, bearing pretty rose-colored flowers, spotted within. $50 \mathrm{cts}$.

R. maximum (Great Laurel) An evergreen shrub, 5 to 30 feet high, with dark green leaves 4 to ro inches long. Flowers white, pink or purple, greenish in the throat and spotted with yellow or red. Takes readily to cultivation. July. Nursery grown, with a good ball of earth attached. 9 to 12 inches, $30 \mathrm{cts}$. each, $\$ 2$ per doz.; I to I $1 / 2$ feet, $50 \mathrm{cts}$. each, $\$ 4$ per doz.; I I 2 to 2 feet, $75 \mathrm{cts}$. eaç, $\$ 6$ per doz. 
RHODORA Canadensis. A low shrub, with showy rose-purple flowers, which precede the leaves in May. $25 \mathrm{cts}$. each, \$1.50 per doz.

RHUS aromatica (Fragrant Sumac). A straggling bush, seldom 3 feet high. Flowers pale yellow, fruit red. $25 \mathrm{cts}$. each, $\$$ 1 75 per doz.

R. copallina (Dwarf Sumac). From 2 to 4 feet high. Leaves very highly colored in autumn. $20 \mathrm{cts}$. each, $\$$ t.25 per doz.

R. glabra (Smooth Sumac). Branches smooth; leaves red in autumn. Forms a bush io to I 5 feet high. $20 \mathrm{cts}$.

R. typhina (Common Staghorn Sumac). Mode of growth similar to R. glabra. The branches are covered with fine hairs. Leaves fine in autumn. $20 \mathrm{cts}$. each, \$I per doz.

R. cotinus (Mist Flower, or Smoke Tree). A small tree, with very fine seed-vessels of a reddish color, giving it a fine appearance. $25 \mathrm{cts}$.

RIBES aureum (Missouri Currant). Flowers yellow, in racemes, quite fragrant. The leaves are highly tinted in autumn. $25 \mathrm{cts}$.

R. Cynostati (Wild Gooseberry). Flowers greenish; berries quite large. 25 cts. each, \$I.25 per doz.

R. floridum (Wild Black Currant). Flowers yellow; currants black and edible. $25 \mathrm{cts}$. each, \$1.25 per doz.

R. prostratum (Fetid Currant). Leaves very showy in autumn. Desirable for rocky places. $20 \mathrm{cts}$.

ROSA blanda (Early Wild Rose). Grows I to 3 feet high. Flowers light rose-color. $25 \mathrm{cts}$. each, $\$$ r.25 per doz.

R. lucida (Dwarf Wild Rose). Seldom over 18 inches high. Flowers rose-color. 25 cts. each, \$I per doz.

R. Carolina (Swamp Rose). A fine native Rose, found in wet or moist places. From 4 to ro feet high. $25 \mathrm{cts}$. Shown on front cover.

RUBUS odoratus (Flowering Raspberry). This shrub is a very pretty one in cultivation. Handsome, dark purple, clustered flowers. $20 \mathrm{cts}$. each, $\$ \mathrm{r} .25$ per doz.

R. deliciosus (Rocky Mountain Rubus). A fine shrub, 3 to 4 feet high, with very large white flowers. I5 cts. each, $\$$ I. 50 der doz.

R. occidentalis (Black Raspberry). The wild black Raspberry so well known to everyone in New England. 20 cts.

R. strigosus (Red Raspberry). This is well known for its fruit in New England. 2oc.

R. villosus (High Blackberry). The common high-bush Blackberry of New England. Fruit ripe in August and September. 3 to 6 feet. 25c. each, $\$$ I. 50 per doz.

SALIX alba (White Willow). A quick grower, desirable for wet places. Plants 2 feet, 15 cts.

S. Babylonica (Babylonian Willow). A weeping Willow, with long slim branches. Plants 2 feet, 5 cts.

SAMBUCUS pubens (Red-Berried Elder). Flowers in broad cymes, white; fruit crimson, in large bunches, very showy. 25 cts. each, $\$$ r.50 per doz.

S. Canadensis (Common Elder). A very beautiful shrub, flowering at a time when most other shrubs are past their bloom. Flowers white. 25c. each, \$I.50 per doz.

SPIRAEA (Meadow Sweet)-

S. argentea. Branches quite drooping; the leaves are not large; flowers small, white, covering the branches. 2 to 3 feet. $25 \mathrm{cts}$.

S. opulifolia. A pretty shrub, with flat heads of white flowers. $25 \mathrm{cts}$. each, $\$ 1.50$ per doz.

S. opulifolia aurea (Golden Spiræa). A very thrifty shrub, growing 6 feet or more, with golden yellow leaves and pure white flowers. $25 \mathrm{cts}$.

S. salicifolia. Flowers in a crowded panicle, white or flesh-colored, 2 to 3 feet high. I5 cts. each, \$1.50 per doz.

S. tomentosa (Steeple Bush). Stems and lower surface of the leaves very woolly. Flowers crowded in a dense panicle, rose-color. I5 cts. each, $\$$ I. 25 per doz.

S. tomentosa aurea. Pure white flowers. 2 feet. $25 \mathrm{cts}$.

S. Thunbergii (Thunberg's Spiræa). In early spring the plant is literally covered with small white flowers. The foliage is light green, changing in autumn to the most beautiful shades, making it one of the most beautiful foliage plants in cultivation. 4 feet. $25 \mathrm{cts}$. each, \$1.50 per doz.

S. Van Houtteii (Van Houtte's Spiræa). The leaves of this variety are oval and toothed at the end, rich green in color, and, like the above, most beautiful in autumn tints. The flowers are pure white, in clusters along the whole length of the branches. $25 \mathrm{cts}$ each, $\$$ r.50 per doz. Large clumps, $50 \mathrm{cts}$. 
STAPHYLEA trifolia (Bladder Nut). About to feet high, with drooping racemes of bell-shaped white flowers. 25 cts.

SYMPHORICARPUS racemosus, var. pauciflorus (Small Snowberry). A pretty little shrub, often scarcely 6 inches high. $25 \mathrm{cts}$. each, \$r.50 per doz.

S. vulgaris (Indian Currant, Coral Berry). Flowers in small clusters; berries dark red. 25 cts.

SYRINGA JAPONICA (Japan Lilac). A fine lawn tree, with glossy green leaves and large bunches of pure white flowers in June. $25 \mathrm{c}$.

S. vulgaris. A fine grower, well known in cultivation ; flowers purple, quite fragrant. 25c.

TAXUS baccata, var. Canadensis (Ground Hemlock). A low evergreen shrub, about 3 feet high. Plant in the shade of other taller shrubs or trees. $25 \mathrm{cts}$. each, $\$ 1.50$ per doz.

THUYA Ellwangeriana. A beautiful form of Arborvitæ, with very short, dark green leaves. Plants $I \frac{1}{2}$ feet high. $35 \mathrm{cts}$.

VACCINIUM Pennsylvanicum (Dwarf Blueberry). 6 to to inches. Berries abundant, large and sweet, ripening early in July. Forms large patches in dry exposed places. $25 \mathrm{cts}$.

v. vacillans (Low Blueberry). The Blueberry of our woods. From I to 2 feet high. Branches yellowish green. $25 \mathrm{cts}$. each, \$1. 25 per doz.

v. stramineum (Deerberry). A handsome shrub about 3 feet high, with striped bark and rather small green leaves. The flowers are greenish white, borne on long stems, followed by the large, delicious blue berries. Easily grown in moist soils. $25 \mathrm{cts}$.

v. corymbosum (Common or Swamp Blue-

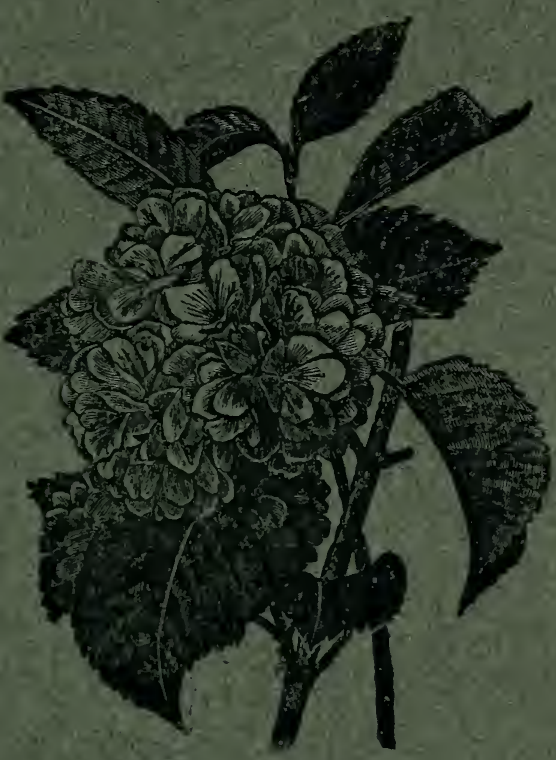

Viburnum (Snowball). berry). Tall, 5 to ro feet high. This yields the common swamp Blueberry so well known in our markets, and is not hard to grow in moist garden soil. $25 \mathrm{cts}$. each, \$I.50 per doz.

VIBURNUM (Arrowwood).

V. acerifolium (Maple-Leaved Arrowwood). Grows 3 feet high, compact in habit Flowers white; leaves highly colored in autumn. $25 \mathrm{cts}$. each, $\$ 1.25$ per doz.

v. cassinoides. One of our handsomest northern shrubs. Grows 6 to Io feet high, with broad, flat cymes of yellowish flowers. Easily cultivated and blooms in great profusion. $25 \mathrm{cts}$. each, \$1.5a per doz.

V. lantanoides (Hobble Bush). Grows 4 to 6 feet high. Leaves round, ovate, 4 to 5 inches wide, highly colored in autumn. Flowers in broad, sessile cymes. Very handsome. $25 \mathrm{cts}$.

V. Lentago (Sheep Berry). Flowers creamy white, in broad, flat sessile cymes, 4 or 5 inches broad. A large shrub or tree, sometimes 30 feet high. $25 \mathrm{cts}$. each, \$1.50 per doz.

V. lantana (Wayfaring Tree). A finely shaped shrub, with good-sized leaves, whitish underneath; fruit red, turning black in autumn. $20 \mathrm{cts}$.

v. nudum (Withe-rod). Shrub 6 to to feet high, with thickish oval leaves. $25 \mathrm{cts}$.

v. Opulus (Cranberry Tree). Grows 5 to ro feet high, with showy white flowers. Fruit bright red, remaining after the leaves are gone. $25 \mathrm{cts}$. each, $\$ 1.50$ per doz.

v. Opulus, var. sterilis (Snowball). Well known in cultivation. $25 \mathrm{cts}$.

V. pubescens (Downy Arrowwood). A compact shrub, 2 to 3 feet high. Has rigid branches and ovate leaves, tapering to a point. Produces in great profusion flat cymes of white flowers. Quite hardy, and is a beautiful plant in cultivation. 25 cts. each, \$r.50 per doz.

V. tomentosum. 8 to to feet. Flowers showy, in flat cymes, pure white. Leaves latge, rich green. $35 \mathrm{cts}$.

viris cordifolia (Frost Grape). Flowers sweet. May and June. Fruit ripens after frost. Wet places along streams. 25 cts. 


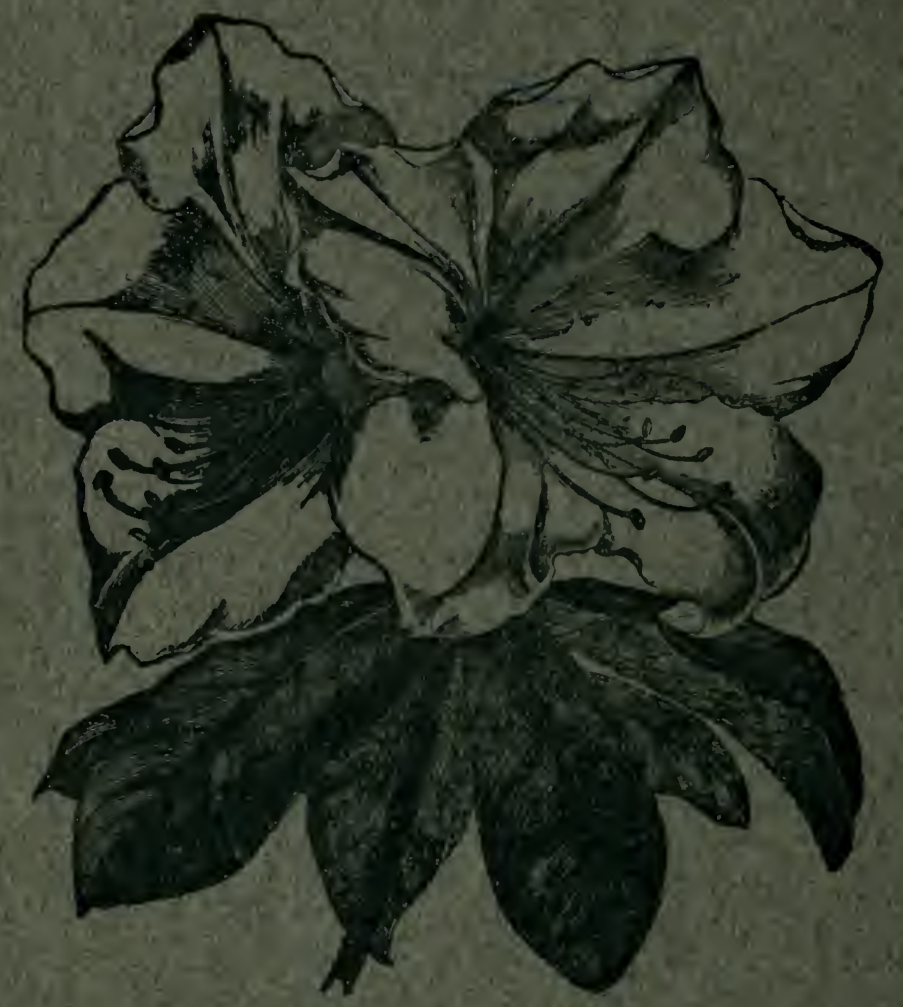

\section{Southwick Nurseries}

EDWARD GILLETT

SOUTHWICK .. MASS. 